\title{
Ginkgolide Derivatives for Photolabeling Studies: Preparation and Pharmacological Evaluation
}

\author{
Kristian Strømgaard, ${ }^{\dagger}$ D. Roland Saito, ${ }^{\dagger}$ Hideo Shindou, ${ }^{\ddagger}$ Satoshi Ishii, ${ }^{\ddagger}$ Takao Shimizu, ${ }^{\ddagger}$ and Koji Nakanishi*,† \\ Department of Chemistry, Columbia University, 3000 Broadway, New York, New York 10027, \\ Department of Biochemistry and Molecular Biology, Faculty of Medicine, The University of Tokyo, Hongo 7-3-1, Bunkyo-ku, \\ Tokyo 113-0033, J apan, and CREST of J apan Science and Technol ogy Corporation, Tokyo 113-0033, J apan
}

Received April 4, 2002

The terpene trilactones (TTLs), ginkgolides and bilobalide, are structurally unique constituents of Ginkgo biloba extracts, which exhibit various neuromodulatory properties. Although the TTLs are believed to be responsible for some of these effects, the specific interactions with targets in the central nervous system remain to be elucidated on a molecular level. Ginkgolides are known antagonists of the platelet-activating factor (PAF) receptor. Herein, we describe the first examination of the binding of native TTLS and their derivatives to the cloned PAF receptor, confirming that of the TTLs, ginkgolide B is the most potent PAF receptor antagonist. Ginkgolide derivatives carrying photoactivatable and fluorescent groups for the purpose of performing photolabeling have been prepared and evaluated using the cloned PAF receptor. These studies have shown that ginkgolide derivatives with aromatic photoactivatable substituents are potent PAF receptor antagonists with $\mathrm{K}_{\mathrm{i}}$ values of $0.09-0.79 \mu \mathrm{M}$ and hence excellent ligands for clarifying the binding of ginkgolides to PAF receptor by photolabeling studies. Ginkgolide derivatives incorporating both fluorescent and photoactivatable groups still retained binding affinity to the PAF receptor and hence should be promising ligands for photolabeling and subsequent sequencing studies.

\section{Introduction}

Ginkgo biloba L., the last surviving member of a family of trees (Ginkgoacea) that appeared more than 250 million years ago, has been mentioned in the Chinese Materia Medica for more than 2500 years. ${ }^{1} \mathrm{~A}$ number of $\mathrm{G}$. biloba natural products have been isolated, ${ }^{2}$ the most unique being the terpene trilactones (TTLs), i.e., ginkgolides A, B, C, J, and M (1-5) and bilobalide (6) (Figure 1). ${ }^{3-6}$ The ginkgolides are diterpenes with a cage skeleton consisting of six fivemembered rings, i.e., a spiro[4.4]nonane carbocycle, three lactones, and a tetrahydrofuran (THF). The difference between the five ginkgolides lies in the variation in the number and positions of hydroxyl groups on the spirononane framework (Figure 1).

A standardized G. bi loba extract (EGb 761) containing TTLs (5-7\%) and flavonoids (22-24\%) has demonstrated neuromodulatory properties, ${ }^{7}$ and several clinical studies using E Gb 761 have reported positive effects on various neurodegenerative diseases, ${ }^{8-13}$ including Alzheimer's disease (AD). ${ }^{14,15} \mathrm{~A}$ recent study by Schultz and co-workers found that E Gb 761 upregulated several genes in rat hippocampus and cortex, including genes expressing proteins such as transthyretin and neuronal tyrosine/threonine phosphatase, both of which are believed to be involved in AD. ${ }^{16}$ Several recent studies on healthy volunteers have shown positive effects of $E G b$ 761 on short-term working memory indicating that

* To whom correspondence should be addressed. Tel: +1 212854 2169. Fax: +1 212932 8273. E-mail: kn5@columbia.edu.

† Columbia University.

₹ The University of Tokyo and CREST of J apan Science and Technology Corp.

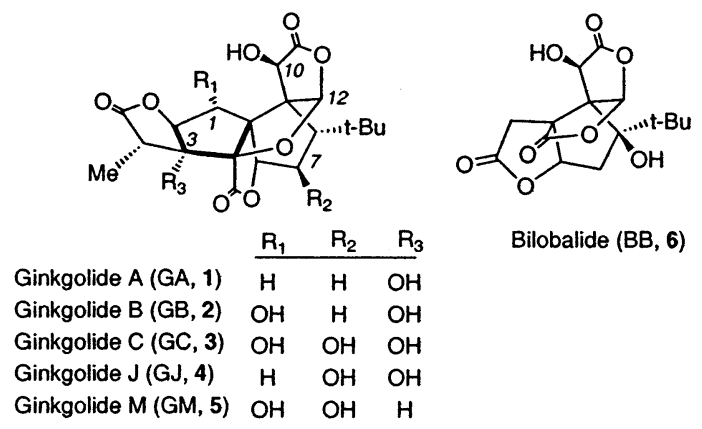

Figure 1. TTLs isolated from G. biloba. GA (1), GB (2), and GC (3) are found in the leaves and root bark of G. biloba, but GJ (4) is found only in the leaves, and GM (5) is found only in the root bark.

constituents of $\mathrm{G}$. bil oba also influence the brain under physiological conditions. ${ }^{17-20}$

Although the molecular basis for the action of $\mathrm{G}$. biloba TTL constituents on the central nervous system (CNS) is only poorly understood, it is known that the ginkgolides, particularly ginkgolide $B(G B, 2)$, is a potent in vitro antagonist of the platelet-activating factor receptor (PAFR). ${ }^{21}$ PAF (1-O-alkyl-2-acetyl-snglycero-3-phosphocholine, Figure 2) is a phospholipid mediator involved in numerous disorders including acute allergy, inflammation, asthma, and ischemic injury. These effects are manifested through binding of PAF to the PAFR, a G protein-coupled receptor that is found in organs such as the lungs, liver, kidneys, ${ }^{22-24}$ and brain. ${ }^{25,26}$ The function of PAF in the brain is still not clear, although PAF has been suggested to play a role in diseases of aging ${ }^{27}$ and in initiating human immunodeficiency virus (HIV)-related neuropathogenesis. ${ }^{28}$ PAF has also been suggested as a retrograde 

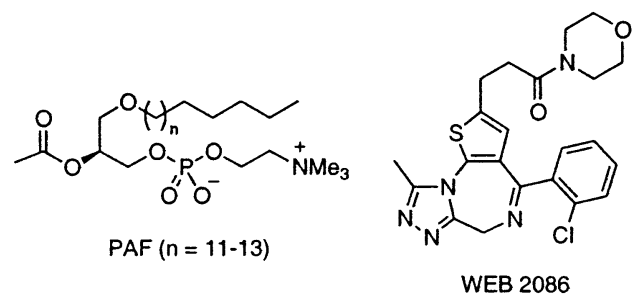

Figure 2. Structures of PAF, the endogenous ligand for the PAFR, and WEB 2086, a potent and selective antagonist, both of which have been used in radioligand binding studies.

messenger in long-term potentiation (LTP). 29,30 However, studies using PAFR knock-out mice gave contradictory results; one study showed attenuation of LTP in the hippocampal dentate gyrus regions of mice lacking the PAF R, ${ }^{31}$ whereas another study showed that the PAF R was not required for LTP in the hippocampal CA1 region. ${ }^{32}$ These discrepancies may be due to differences in the hippocampal areas observed, as well as the assay conditions used. However, it is still unclear whether the neuromodulatory effect of TTLs or G. biloba extract is related to the PAFR.33,34

With few exceptions, previous structure-activity relationship (SAR) studies of TTLS on the PAFR have focused almost entirely on derivatives of GB (2). In all cases, the derivatives were evaluated for their ability to prevent PAF-induced aggregation of rabbit platelets. Corey et al. investigated various intermediates encountered during the course of the total syntheses of ginkgolide $A(G A, \mathbf{1}),{ }^{35} \mathrm{~GB}(\mathbf{2}),{ }^{36}$ and bilobalide $(B B, 6)^{37}$ and found that although the terminal methyl-bearing lactone was not essential for activity and could be replaced by other lipophilic groups, ${ }^{38}$ the tert-butyl group was important for PAFR antagonism. ${ }^{39}$ Park et al. synthesized over 200 derivatives of GB (2), with particular focus on aromatic substituents at $10-\mathrm{OH}$, and found most of them to be more potent than the parent compound. ${ }^{40}$ Similar derivatives recently synthesized by $\mathrm{Hu}$ et al. also yielded compounds more potent than GB (2), ${ }^{41,42}$ whereas other variations in GA (1) and GB (2) led to a decrease in activity. ${ }^{43,44}$

In the following, we describe the first evaluation of the interaction of all native ginkgolides and bilobalide with the cloned PAFR by a radioligand binding assay, as well as their functional properties by intracellular calcium measurements. A series of ginkgolide derivatives with photoactivatable and fluorescent groups have been prepared, and these anal ogues have been assessed for their ability to displace radioligand binding to cloned PAFR.

\section{Results}

Synthesis. A series of photoactivatable GB (2) and ginkgolide C (GC, 3) derivatives were designed based on previous SAR studies of ginkgolides, which demonstrated that bulky aromatic substituents in the $10-\mathrm{OH}$ position of GB (2) increase activity at the PAFR. ${ }^{40-42}$ Three different photoactivatable moieties, benzophenone, trifluoromethyldiazirine, and tetrafluorophenyl azide, were chosen as they have been described as being among the most successful for labeling receptors and enzymes. ${ }^{45-47}$ M ost importantly, upon irradiation, these photoactivatable groups react with the receptor via different intermediates, namely, a radical, a carbene, or a (singlet) nitrene for the benzophenone, trifluoromethyldiazirine, and tetrafluorophenyl azide moi eties, respectively. ${ }^{45}$ Because it is essentially impossible to predict which group will be most readily incorporated into the receptor, use of these different groups increases the likelihood of a successful incorporation.

4-(Bromomethyl)benzophenone was commercially available, whereas trifluoromethyldiazirine $\mathbf{1 2}^{\mathbf{4 8 , 4 9}}$ and tetrafluorophenyl azide $\mathbf{1 5}^{50-52}$ were synthesized, respectively, as outlined in Scheme 1. The bromotrifluoromethyl diazirine $\mathbf{1 2}$ was synthesized starting from readily available 4-bromotoluene, which was reacted with $\mathrm{N}$ trifluoroacetyl pi peridine ${ }^{48}$ to give trifluoroacetyl toluene 7. The trifluoroacetyl compound $\mathbf{7}$ was then reacted with hydroxylamine hydrochloride in pyridine to form oxime 8. Reacting the latter with p-toluenesulfonyl chloride led to the tosylated oxime $\mathbf{9}$, which was placed in a thickwalled screw-capped flask and reacted overnight with liquid ammonia in di ethyl ether to form the diazi ridine 10; under dim red light, diaziridine $\mathbf{1 0}$ was oxidized with iodine to give methylphenyl-trifluoromethyl-diazirine 11. F inally, 11 was brominated with $\mathrm{N}$-bromosuccinimide (NBS) using a catalytic amount of 2,2'-azobi sisobutyronitrile (AIBN) to form 3-(4-bromomethyl phenyl)-3trifluoromethyl-3H-diazirine (12, Scheme 1). Benzoyl peroxide was initially used as a radical initiator, but the reaction yielded multiple products resulting from multiple bromine substitutions. The use of AIBN led to a 4:1 ratio of monobromiated $\mathbf{1 2}$ and geminal dibromosubstituted methylphenyl-trifluoromethyldiazirine, but

\section{Scheme $1^{\text {a }}$}

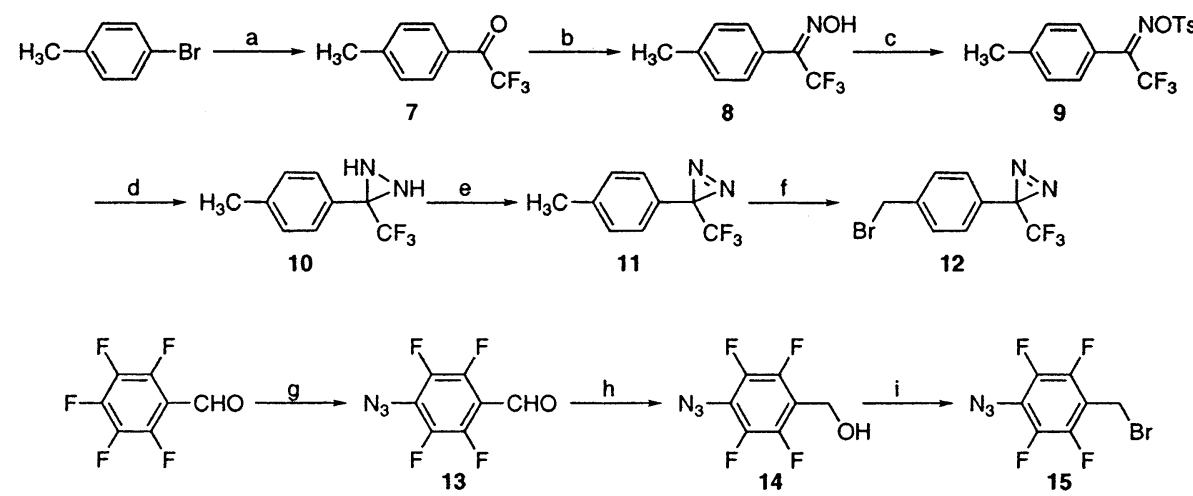

a Reagents: (a) N-Trifluoroacetylpiperidine, n-butyllithium. (b) Hydroxylamine. (c) p-Toluenesulfonyl chloride, pyridine. (d) $\mathrm{NH}_{3}$. (e) $I_{2}$, Et $t_{3}$. (f) NBS, AIBN. (g) $\mathrm{NaN}_{3}$. (h) $\mathrm{Me}_{2} \mathrm{NHBH}_{3}$. (i) $\mathrm{PBr}_{3}$. 


\section{Scheme $2^{\mathrm{a}}$}
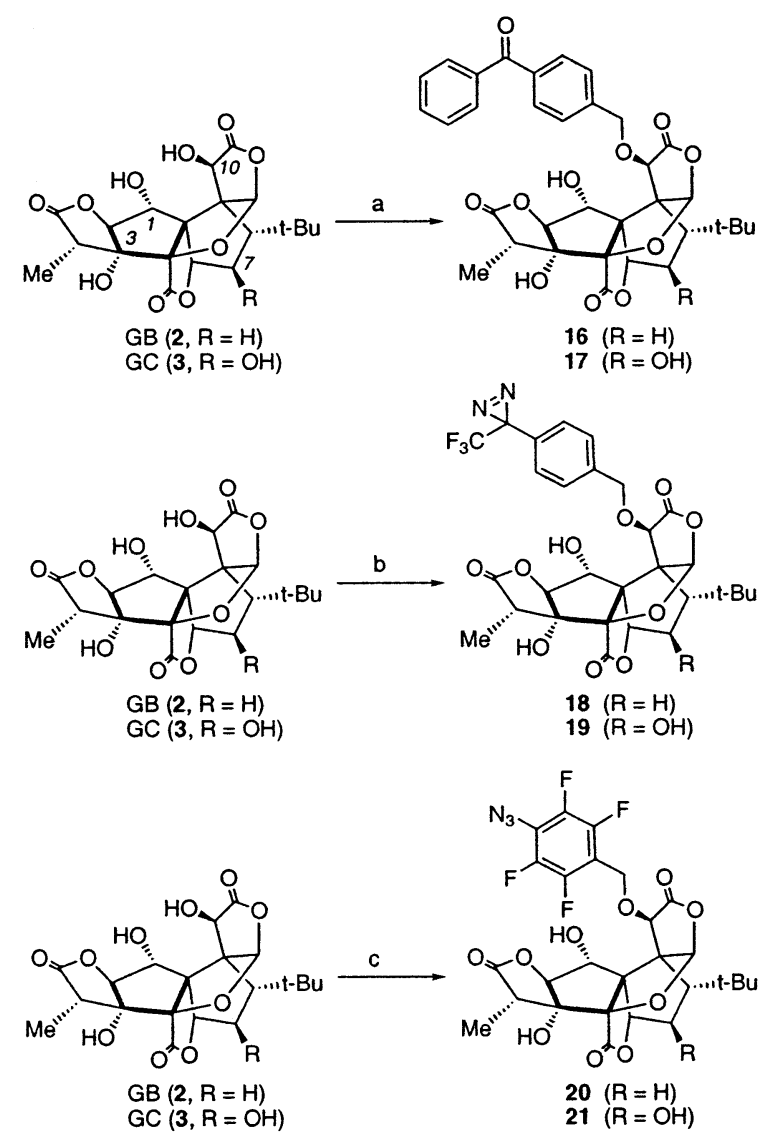

a Reagents: (a) 4-(Bromomethyl)benzophenone, KH. (b) Compound 12, KH. (c) Compound 15, KH.

separation of the two products required several repetitions of flash column chromatography to yield the monobromo-substituted diazirine $\mathbf{1 2}$ in sufficient purity.

For the synthesis of tetrafluorophenyl azide 15, pentafluorobenzal dehyde was heated with sodium azide in an acetone-water mixture. Because pentafluorophenyl groups that contain electron-withdrawing groups undergo nucleophilic aromatic substitution regioselectively in the para position, azidophenylaldehyde $\mathbf{1 3}$ was obtained in high yield, and no ortho-substituted product was observed. Aldehyde $\mathbf{1 3}$ was sel ectively reduced with a dimethylamine-borane complex to form the benzyl al cohol 14. The benzyl al cohol $\mathbf{1 4}$ was then brominated by refluxing with phosphorus tribromidein pyridine and chloroform to give the desired product 15 (Scheme 1).

Preparation of GB and GC derivatives 16-21 was performed by reacting GB (2) and GC (3) with 4-(bromomethyl)benzophenone, 3-(4-bromomethyl phenyl)-3trifluoromethyl-3H-diazirine (12), and 1-azido-4-(bromomethyl)-2,3,5,6-tetrafluorobenzene (15), respectively (Scheme 2). Ginkgolides GB (2) and GC (3) were derivatized almost exclusively at $10-\mathrm{OH}$ when potassium hydride $(\mathrm{KH})$ was used as base, as was previously shown for GB (2), ${ }^{40}$ whereas other bases were less selective, giving rise to products derivatized at $1-\mathrm{OH}$ as well. It is noteworthy that 7-OH present in GC (3) does not react under any of the above-mentioned reaction conditions. Generally, the position of the substituent was determined from the ${ }^{1} \mathrm{H}$ NMR coupling of appropriate protons in dimethyl sulfoxide (DMSO)- $\mathrm{d}_{6}$, as well as by correlation spectroscopy (COSY) spectra. The
Scheme $3^{a}$
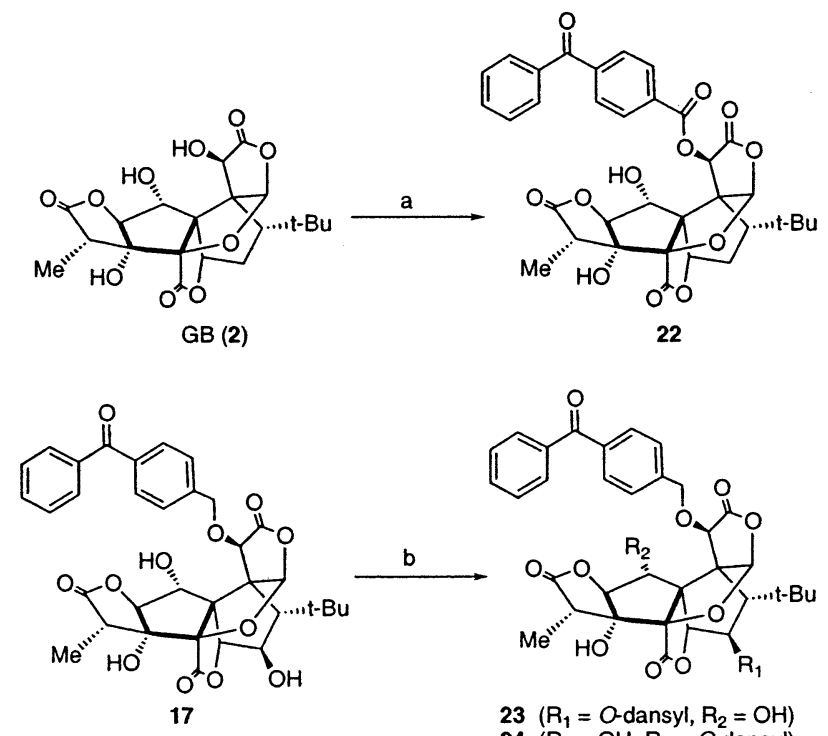

$23\left(\mathrm{R}_{1}=\mathrm{O}\right.$-dansyl, $\left.\mathrm{R}_{2}=\mathrm{OH}\right)$ $24\left(\mathrm{R}_{1}=\mathrm{OH}, \mathrm{R}_{2}=\mathrm{O}_{\text {-dansyl })}\right.$

a Reagents: (a) 4-Benzoylbenzoic acid, EDC, DMAP. (b) Dansyl chloride, DMAP.

relative chemical shift of $12-\mathrm{H}$ in DMSO- $\mathrm{d}_{6}$ can also be used in differentiating 1- and 10-OH substitutions. ${ }^{42}$

The coupling of GB (2) with 4-benzoylbenzoic acid using 1-[3-(dimethylamino)propyl]-3-ethylcarbodiimide $\mathrm{HCl}$ (EDC) and 4-(dimethylamino)pyridine (DMAP) occurred exclusively at 10-OH to give 10-benzophenonecarbonyl GB (22) in good yield (Scheme 3). In 10benzophenonecarbonyl GB (22), the photoactivatable benzophenone moiety is linked to the ginkgolide skeleton through an ester linkage. After it is incorporated into the receptor, the ester group can be aminolyzed with a fluorescent amine such as 1-pyrenemethylamine, thus avoi ding the use of radioactivity for photolabeling and sequencing. 54

GC derivatives 17, 19, and $\mathbf{2 1}$ can be reacted further to incorporate fluorescent groups; for example, benzophenone derivative $\mathbf{1 7}$ was reacted with 1 equiv of 5-(dimethylamino)naphthalene-sulfonyl (dansyl) chloride to give 10-O-benzophenone-7-O-dansyl GC (23) with almost exclusive reaction at $7-\mathrm{OH}$ (Scheme 3). Interestingly, increasing the amount of dansyl chloride to 2 equiv gave 10-O-benzophenone-1-O-dansyl GC (24) as well as $\mathbf{2 3}$ in a 1:1 ratio.

All compounds were characterized by NMR spectroscopy and high-resolution mass spectrometry (HRMS). Purity of the derivatives 16-24, with aromatic groups, was determined by high-performance liquid chromatography (HPLC)-UV and ${ }^{1} \mathrm{H} N M R$ and was in the range of $98-100 \%$. Because ginkgolides (1-5) and bilobalide (6) absorb only weakly in the UV spectrum, HPLC-UV cannot be used for determination of purity. Instead, observation of the $12-\mathrm{H}^{1} \mathrm{H}$ NMR signal of $\mathbf{1}-\mathbf{6}$ is a particularly useful way to determine purity, as this signal has distinct and well-separated $\delta$-values for ginkgolides, bilobalide, and their derivatives.

Pharmacology. The native TTLs (1-6), as well as ginkgolide derivatives 16-24, were tested for their ability to bind to PAFR using a radioligand binding assay with membrane fractions from hearts and skel etal muscles of PAF R transgenic mice. ${ }^{53}$ I nitially, compounds were tested in concentrations of $5 \mu \mathrm{M}$ against [ ${ }^{3} \mathrm{H}$ ]WE $\mathrm{B}$ 
Table 1. $\mathrm{K}_{i}$ Values of the Native TTLs

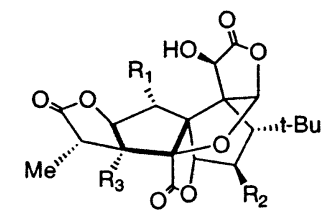

\begin{tabular}{lcccc}
\hline \multicolumn{1}{c}{ compd } & $\mathrm{R}_{1}$ & $\mathrm{R}_{2}$ & $\mathrm{R}_{3}$ & $\mathrm{~K}_{\mathrm{i}}(\mu \mathrm{M})^{\mathrm{a}}$ \\
\hline GA (1) & $\mathrm{H}$ & $\mathrm{H}$ & $\mathrm{OH}$ & 1.46 \\
GB (2) & $\mathrm{OH}$ & $\mathrm{H}$ & $\mathrm{OH}$ & 0.56 \\
GC (3) & $\mathrm{OH}$ & $\mathrm{OH}$ & $\mathrm{OH}$ & 12.6 \\
GJ (4) & $\mathrm{H}$ & $\mathrm{OH}$ & $\mathrm{OH}$ & 9.90 \\
GM (5) & $\mathrm{OH}$ & $\mathrm{OH}$ & $\mathrm{H}$ & $>50$ \\
bilobalide (6) & & & & $>50$ \\
\hline
\end{tabular}

a Inhibition of [ ${ }^{3} \mathrm{H}$ ]WE B 2086 binding. Values are means of two independent experiments performed in triplicate.

2086 (Figure 2), a potent, competitive PAF R antagonist and $\left[{ }^{3} \mathrm{H}\right] \mathrm{PAF}$; the compounds were generally less potent against $\left[{ }^{3} \mathrm{H}\right] \mathrm{PAF}$, but the relative potencies were comparable with the two radioligands. The degree of nonspecific binding was determined to be ca. $50 \%$ for $\left[{ }^{3} \mathrm{H}\right] \mathrm{PAF}$ and less than $5 \%$ for $\left[{ }^{3} \mathrm{H}\right]$ WE B 2086 . Accordingly, the assays were performed using $\left[{ }^{3} \mathrm{H}\right] \mathrm{WWE} B 2086$ rather than $\left[{ }^{3} \mathrm{H}\right] \mathrm{PAF}$ as the radioligand, due to the high degree of nonspecific binding of the latter.

All compounds were dissolved in DMSO to obtain 5 $\mathrm{mM}$ stock solutions of test compounds. Examination of the effect of DMSO on the binding of $\left[{ }^{3} \mathrm{H}\right]$ WEB 2086 revealed that up to $1 \%$ DMSO (final concentration) was acceptable, but $1-2.5 \%$ resulted in a slight inhibition of $\left[{ }^{3} \mathrm{H}\right]$ WEB 2086 binding. Generally, this caused no problem; however, with very weakly binding compounds, the relatively high DMSO concentration in solutions above $100 \mu \mathrm{M}$ had a small inhibitory effect, thus leading to a slight overestimation of their potencies. Previous studies have reported problems associated with the solubilization of ginkgolides specifically in DMSO, 55 but similar problems were not observed in the present study.

Native ginkgolides (1-5) and bilobalide (6) were tested with the cloned PAFR (Table 1). GB (2) was the most potent compound with a $K_{i}$ value of $0.56 \mu \mathrm{M}$, while GA (1) was slightly less potent with a $K_{i}$ of $1.46 \mu \mathrm{M}$. GC (3) and ginkgolide J (GJ , 4) were significantly less potent, while ginkgolide $M(G M, 5)$ and bilobalide (6) both had $\mathrm{K}_{i}$ values larger than $50 \mu \mathrm{M}$.

The GB-derived photoactivatable compounds 16, 18, 20, and 22 with $K_{i}$ values in the range 0.09-0.15 $\mu \mathrm{M}$ (Table 2) were all more potent than GB (2), while compounds 17, 19, and 21 derived from GC (3) with $\mathrm{K}_{i}$ values of $0.47-0.79 \mu \mathrm{M}$ were equipotent to GB (2) (Table 2), despite the fact that GC (3) itself is only weakly potent. Besides proving that aromatic groups linked to $10-\mathrm{OH}$ enhance activity in both GB (2) and GC (3) derivatives, these results also indicate that the specific type of photoactivatable group was less important. Derivatives $\mathbf{2 3}$ and $\mathbf{2 4}$ possessing a fluorescent dansyl group at either 1- or 7-OH were both less potent than 10-O-benzophenone GC (17) without the dansyl group, with $K_{i}$ values of 3.94 and $0.96 \mu \mathrm{M}$ for $\mathbf{2 3}$ and $\mathbf{2 4}$, respectively. However, an important difference was observed in the activities between the two; the 1- and 10-disubstituted anal ogue (24) was ca. four times more potent than the 7- and 10-disubstituted analogue (23).
Table 2. $\mathrm{K}_{\mathrm{i}}$ Values of the Synthesized Derivatives

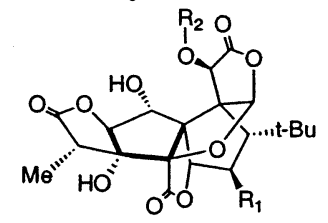

\begin{tabular}{|c|c|c|c|}
\hline compd & $\mathrm{R}_{1}$ & $\mathrm{R}_{2}$ & $K_{\mathrm{i}}(\mu \mathrm{M})^{a}$ \\
\hline 16 & $\mathrm{H}$ & & 0.15 \\
\hline 17 & $\mathrm{OH}$ & & 0.58 \\
\hline 18 & $\mathrm{H}$ & & 0.15 \\
\hline 19 & $\mathrm{OH}$ & & 0.47 \\
\hline 20 & $\mathrm{H}$ & & 0.09 \\
\hline 21 & $\mathrm{OH}$ & & 0.79 \\
\hline 22 & $\mathrm{H}$ & & 0.13 \\
\hline
\end{tabular}

a Inhibition of [ $\left.{ }^{3} \mathrm{H}\right]$ WE B 2086 binding. Values are means of two independent experiments performed in triplicate.

PAFR is linked to several intracellular signal transduction pathways including elevation of intracellular calcium concentration, ${ }^{22}$ which can be used for analyzing functional responses of PAFR ligands..$^{56}$ In the present study, the compounds with $K_{i}$ values below $5 \mu \mathrm{M}$, i.e., GA (1), GB (2), and anal ogues 16-22, were investigated for their ability to mobilize intracellular calcium in Chinese hamster ovary ( $\mathrm{CHO}$ ) cells expressing the PAFR. ${ }^{57}$ While none of them evoked calcium responses, they all suppressed PAF-induced intracellular calcium increase (data not shown) confirming their function as PAFR antagonists. Because the assay is based on the measurement of the fluorescence of a $\mathrm{Ca}^{2+}$ sensitive dye, the fluorescence of analogues $\mathbf{2 3}$ and $\mathbf{2 4}$ interfered with the measurement and could not be assayed.

\section{Discussion}

Nine analogues (16-24) with photoactivatable groups, and in the case of $\mathbf{2 3}$ and $\mathbf{2 4}$ with fluorescent dansyl groups as well, have been prepared from native ginkgolides GB (2) and GC (3) by selective derivatizations of the hydroxyl groups. Generally, the increased reactivity of the $1-\mathrm{OH}$ and $10-\mathrm{OH}$ as compared to $7-\mathrm{OH}$ has been rationalized by stabilization of the corresponding alkoxides by hydrogen bonding between $1-\mathrm{OH}$ and $10-$ $\mathrm{OH},{ }^{58}$ but this does not explain the interesting sel ectivity for the $10-\mathrm{OH}$ position in reactions with benzyl bromi de derivatives. Notably, reaction of GC (3) with a bulky silyl chloride protection group occurs exclusively at the 1-OH of GC. ${ }^{59}$ Three different photoactivatable moieties, all of them benzyl derivatives, were incorpo- 


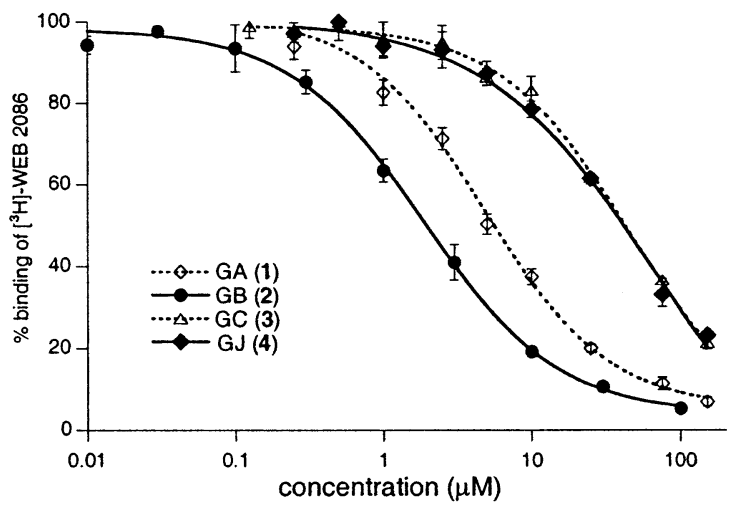

Figure 3. Concentration-displacement curves for native TTLS, as measured by their ability to displace binding of $\left[{ }^{3} \mathrm{H}\right]-$ WEB 2086 to the cloned PAFR. GB (2) was the most potent analogue, while GA (1) was slightly less potent, and GC (3) and GJ (4) were only weak antagonists. Bars represent the standard deviation (SD).

rated into both GB and GC. The benzophenone moiety was commercially available, whereas trifluoromethyldiazirine $\mathbf{1 2}$ and tetrafluorophenyl azide $\mathbf{1 5}$ moieties were synthesized in six and three steps, respectively (Scheme 1). The three different types of photoactivatable groups were selected on the basis of their different reactive intermediates when irradiated, the intermediates being a radical, a carbene, and (singlet) nitrene for benzophenone, trifluoromethyldiazirine, and tetrafluorophenyl azide, respectively.

All native TTLs (1-6) as well as the derivatized compounds were investigated with respect to their binding to cloned PAFR isolated from transgenic mice (Figure 3 and 4). To the best of our knowledge, this is the first report on the effect of TTLs on the cloned PAFR, since previous SAR studies of PAFR antagonism with TTL $s$ and derivatives was performed by monitoring inhibition of PAF-induced rabbit platelet aggregation. GB (2) has generally been reported to be a potent antagonist of the PAFR based on the latter assay with an I $\mathrm{C}_{50}$ value around $0.2 \mu \mathrm{M},{ }^{40-42}$ which corresponds to the $K_{i}$ value of $0.56 \mu \mathrm{M}$ obtained in this study (Table 1). GA (1), with one hydroxyl group less than GB (2), was only slightly less potent than GB (2, Figure 3), indicating that the $\mathrm{OH}-1$ is not essential for activity, and neither is the hydrogen bonding between $\mathrm{OH}-1$ and $\mathrm{OH}-10$. Generally, the binding of GC (3), GJ (4), and GM (5) with hydroxyl groups at C-7, as compared to the binding activity of GA (1) and GB (2) lacking the 7-OH, was decreased showing that the 7-OH is not necessary for binding to PAFR whereas hydroxyl groups at other positions appear to be less important (Figure 3). The study al so confirmed that bilobalide (6), a TTL with only one five-membered carbocycle and three lactones, is not displacing [ ${ }^{3} \mathrm{H}$ ]WE B 2086 binding in concentrations up to $100 \mu \mathrm{M}$ (Table 1 ).

All seven photoactivatable analogues 16-22 with aromatic substituents at $10-\mathrm{OH}$ improved the affinity to the PAFR relative to the activities of GB (2) and GC (3) (Figure 4). This is in agreement with previous SAR studies of GB (2), ${ }^{40-42}$ as well as a three-dimensional (3D)-quantitative SAR (QSAR) study on ginkgolides. ${ }^{60}$ However, it is interesting to note that aromatic substitutions at 10-OH of GC (3) as in compounds 17, 19, and 21 improve the affinity to PAFR ca. 20-fold thus making
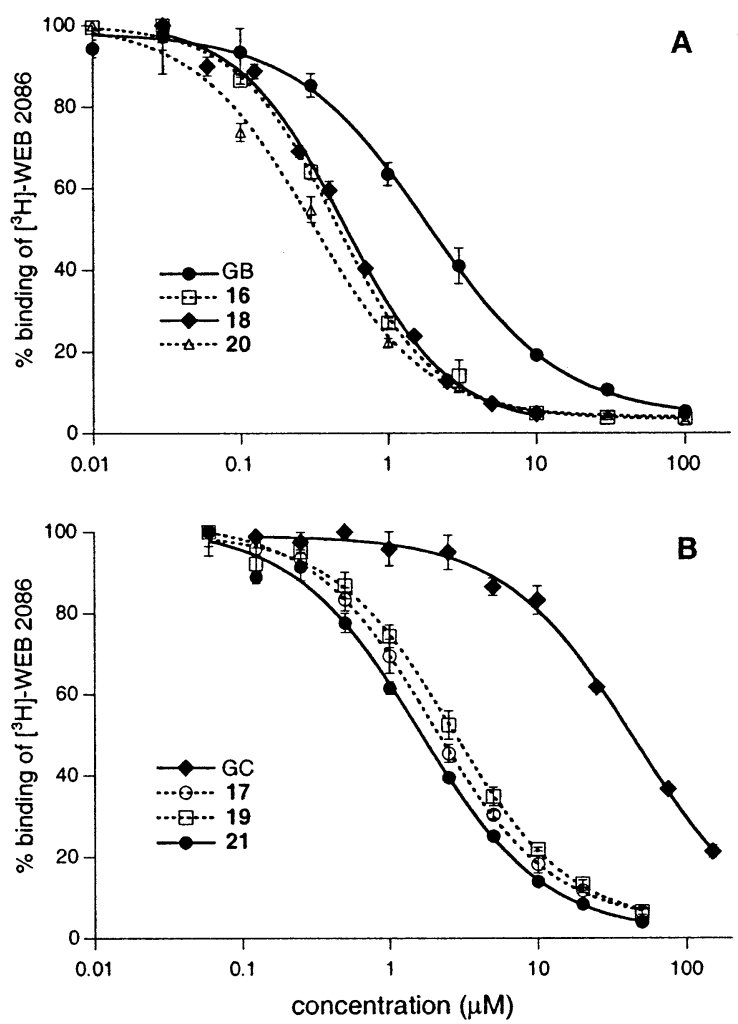

Figure 4. (A) GB (2) and photoactivatable benzyl derivatives; the three photoactivatable derivatives $\mathbf{1 6}, \mathbf{1 8}$, and $\mathbf{2 0}$ were all ca. 6-fold more potent than GB (2), and the activities were remarkably similar although bearing very different functional groups. (B) GC (3) and photoactivatable benzyl derivatives (17, 19, and 21) were all more potent than GC (3), with a remarkable increase in potency, thus being equipotent to GB (2). Bars represent the SD.

them equipotent to GB (2), while the same substitutions in GB (2) increase the affinity only 6-fold (Figure 4). Furthermore, the similar affinities of GB derivatives $\mathbf{1 6}$, 18, 20, and 22 and the similar affinities of GC derivatives 17, 19, and $\mathbf{2 1}$ (Figure 4) imply that it is the steric bulk or the lipophilicity, including $\pi-\pi$ interactions of the substituents, rather than the specific functional groups that are important for the increase in affinity.

GC derivatives $\mathbf{2 3}$ and $\mathbf{2 4}$ (Scheme 3) with dansyl groups at 7-OH and 1-OH are less potent and equipotent, respectively, to their parent compound, 10-Obenzophenone-GC (17). In compound $\mathbf{2 3}$, which is ca. six times less active than $\mathbf{1 7}$, the bulk at the 7-position seems to be responsible for the reduction in affinity. The fact that compound $\mathbf{2 4}$ is equipotent to $\mathbf{1 7}$ suggests that once a bulky aromatic group occupies this area, further aromatic groups neither increase nor decrease the affinity.

In conclusion, an investigation of the effect of TTLs isolated from G. biloba on the cloned PAFR has demonstrated that among the native compounds, GA (1) and GB (2) are the most potent. A series of photoactivatable analogues have been prepared, and PAFR binding assays showed that most of these analogues were more potent antagonists than their parent compounds, thus providing promising candidates for the planned studies of the interaction of ginkgolides with the PAFR. The ginkgolide derivative containing both a photoactivatable and a fluorescent group, compound $\mathbf{2 4}$, retained affinity 
to PAFR and thus could be useful in photolabeling and subsequent sequencing studies.

\section{Experimental Section}

Chemistry. General Procedures. Ginkgolides and bilobalide (1-6) were obtained by extraction of leaves from G. biloba, purification by column chromatography, and recrystallization, as previously described, ${ }^{3,61}$ and purity was $>99 \%$ as determined by ${ }^{1} \mathrm{H}$ NMR. Solvents were dried by eluting through al umi na columns. Triethylamine was freshly distilled from $\mathrm{NaOH}$ pellets. Unless otherwise noted, materials were obtained from a commercial supplier and were used without further purification. All reactions were performed in predried glassware under argon or nitrogen, and all reactions involving azides or diazirines were performed in dim red light. Flash column chromatography was performed using ICN silica gel (32-63 mesh) or ICN silica gel (32-63 mesh) impregnated with sodium acetate. ${ }^{61}$

Thin-layer chromatography (TLC) was carried out using precoated silica gel $60 \mathrm{~F}_{254}$ plates with thickness of $0.25 \mu \mathrm{m}$. Spots were observed at $254 \mathrm{~nm}$ and by staining with acetic anhydride or cerium/molybdenum in $\mathrm{H}_{2} \mathrm{SO}_{4} .{ }^{1} \mathrm{H}$ and ${ }^{13} \mathrm{C} \mathrm{NMR}$ spectra were obtained on Bruker DMX 300 or Bruker DMX $400 \mathrm{MHz}$ spectrometers and are reported in parts per million (ppm) relative to internal solvent signal, with coupling constants $(J)$ in Hertz $(\mathrm{Hz})$. For ${ }^{19} \mathrm{~F}$ NMR spectra, hexafluorobenzene (-162.9 ppm) was used as internal standard. Analytical HPLC was performed on a HP 1100 LC instrument using a 5 $\mu \mathrm{m}$ C18 reversed-phase Phenomenex Luna col umn ( $150 \mathrm{~mm}$ $\times 4.60 \mathrm{~mm}$ ), using $1 \mathrm{~mL} / \mathrm{min}$ of water/acetonitrile/TFA $60: 40$ : 0.1 , raising to $50: 50: 0.1$ after $10 \mathrm{~min}$, and detecting by UV at 219 and $254 \mathrm{~nm}$. Accurate mass determination was performed on a J EOL J MS-HX110/100A HF mass spectrometer using a 3-nitrobenzyl alcohol (NBA) matrix and Xe ionizing gas, and all are within $\pm 5 \mathrm{ppm}$ of theoretical values.

2,2,2-Trifluoro-1-(4-methylphenyl)-1-ethanone (7).48 4-Bromotoluene $(9.45 \mathrm{~g}, 55.25 \mathrm{mmol})$ was dissolved in $\mathrm{Et}_{2} \mathrm{O}$ $(280 \mathrm{~mL})$ and cooled to $-40{ }^{\circ} \mathrm{C}$. n-Butyllithium (1.1 M in hexane, $40.5 \mathrm{~mL}, 60.74 \mathrm{mmol}$ ) was added dropwise, and the solution was warmed to $0{ }^{\circ} \mathrm{C}$ over a $2 \mathrm{~h}$ period. The solution was then cooled to $-60{ }^{\circ} \mathrm{C}$ and a solution of $\mathrm{N}$-trifluoroacetyl piperidine ${ }^{48}(10.00 \mathrm{~g} 55.23 \mathrm{mmol})$ in dry Et ${ }_{2} \mathrm{O}(60 \mathrm{~mL})$ was added in portions. The reaction was allowed to stir at -60 ${ }^{\circ} \mathrm{C}$ for $3 \mathrm{~h}$ and then warmed to room temperature. The solution was hydrolyzed with saturated $\mathrm{NH}_{4} \mathrm{Cl}(50 \mathrm{~mL})$ and washed with $\mathrm{NH}_{4} \mathrm{Cl}(5 \times 50 \mathrm{~mL})$ and $\mathrm{H}_{2} \mathrm{O}(3 \times 50 \mathrm{~mL})$. The organic phase was dried $\left(\mathrm{MgSO}_{4}\right)$, and the solvent was removed in vacuo. The remaining oil was purified by flash column chromatography eluting with hexane/ $\mathrm{CH}_{2} \mathrm{Cl}_{2}(5: 1,4: 1$, and 3:1) to give a colorless oil $(5.62 \mathrm{~g}, 54 \%)$. ${ }^{1} \mathrm{H}$ NMR $\left(300 \mathrm{MHz}, \mathrm{CDCl}_{3}\right)$ : $\delta 2.46(\mathrm{~s}, 3 \mathrm{H}), 7.26-7.36$ and $7.96-7.98$ ( $\mathrm{AA}^{\prime} \mathrm{BB}^{\prime}$ system, 4H). ${ }^{13} \mathrm{C} \mathrm{NMR}\left(75 \mathrm{MHz}, \mathrm{CDCl}_{3}\right): \delta 22.3,117.0\left(\mathrm{q},{ }^{\mathrm{I}} \mathrm{J} \mathrm{CF}=292.5, \mathrm{CF}_{3}\right)$, $127.9,130.2(2 \mathrm{C}), 130.7(2 \mathrm{C}), 147.4,169.1\left(\mathrm{q},{ }^{2} \mathrm{CF}=60.0\right)$.

2,2,2-Trifluoro-1-(4-methylphenyl)-1-ethanone Oxime (8). ${ }^{48}$ Ketone 7 ( $\left.2.60 \mathrm{~g}, 13.80 \mathrm{mmol}\right)$ was dissolved in pyridine $(30 \mathrm{~mL})$, hydroxylamine hydrochloride $(2.88 \mathrm{~g}, 41.44 \mathrm{mmol})$ was added, and the reaction was stirred at $70{ }^{\circ} \mathrm{C}$ for $3 \mathrm{~h}$. Pyridine was removed in vacuo, and the remaining residue was dissolved in $\mathrm{Et}_{2} \mathrm{O}(50 \mathrm{~mL})$ and washed with $0.01 \mathrm{M} \mathrm{HCl}$ (50 mL). The organic layer was washed with $\mathrm{H}_{2} \mathrm{O}(3 \times 50 \mathrm{~mL})$ and dried $\left(\mathrm{MgSO}_{4}\right)$, and the solvent was removed in vacuo to give a colorless solid ( $2.01 \mathrm{~g}, 72 \%)$, which was used without further purification. ${ }^{1 \mathrm{H}} \mathrm{NMR}\left(300 \mathrm{MHz} \mathrm{CDCl}_{3}\right): \delta 2.40$ (s, $3 \mathrm{H}), 7.20-7.30$ and $7.37-7.43(\mathrm{~m}, 4 \mathrm{H}), 8.38$ (bs, OH). Multiple splitting patterns arise due to anti/syn configurations of the oxime. ${ }^{13} \mathrm{C}$ NMR $\left(75 \mathrm{MHz} \mathrm{CDCl}_{3}\right): \delta 21.9,121.0\left(\mathrm{q},{ }^{1} \mathrm{~J}_{\mathrm{CF}}=\right.$ 277.5, $\left.\mathrm{CF}_{3}\right), 123.4,129.0(2 \mathrm{C}), 129.7$ (2C), 141.4, 148.4 (q, ${ }^{2} \mathrm{JF}$ $=37.5$ ).

2,2,2-Trifluoro-1-(4-methylphenyl)-1-ethanone 0-(pToluenesulfonyl) Oxime (9). ${ }^{48}$ To a stirred solution of oxime $8(2.00 \mathrm{~g}, 9.85 \mathrm{mmol})$ in pyridine $(36 \mathrm{~mL}), \mathrm{p}$-toluenesulfonyl chloride $(2.82 \mathrm{~g}, 14.79 \mathrm{mmol})$ was added in portions and the reaction mixture was refluxed for $3 \mathrm{~h}$. Pyridine was removed in vacuo, and the residue was purified by flash column chromatography eluting with hexane/ $\mathrm{CH}_{2} \mathrm{Cl}_{2}(2: 1)$ to give a white solid $(2.90 \mathrm{~g}, 82 \%)$. ${ }^{1} \mathrm{H}$ NMR $\left(300 \mathrm{MHz} \mathrm{CDCl}_{3}\right): \delta 2.40$ $(\mathrm{s}, 3 \mathrm{H}), 2.48(\mathrm{~s}, 3 \mathrm{H}), 7.26-7.34(\mathrm{~m}, 4 \mathrm{H}), 7.37-7.40$ and $7.87-$ 7.90 (AA'BB' system, tosyl aromatic H, 4H). ${ }^{13} \mathrm{C}$ NMR $(75 \mathrm{MHz}$, $\left.\mathrm{CDCl}_{3}\right): \delta 21.9,22.2,120.0\left(\mathrm{q},{ }^{1} \mathrm{~J} \mathrm{CF}=285.0, \mathrm{CF}_{3}\right), 122.0,128.9$ (2C), 129.7 (2C), 129.9 (2C), 130.2 (2C), 132.0, 142.7, 146.4, $154.0\left(\mathrm{q},{ }^{2} \mathrm{~J} \mathrm{CF}=67.5\right)$.

3-(4-Methylphenyl)-3-trifluoromethyldiaziridine (10).48 In a thick-walled screw-cap tube, $9(2.90 \mathrm{~g}, 8.12 \mathrm{mmol})$ was dissolved in $\mathrm{Et}_{2} \mathrm{O}(20 \mathrm{~mL})$. The solution was cooled to $-78^{\circ} \mathrm{C}$, and liquid ammonia ( $3.5 \mathrm{~mL}$ ) was added. The tube was screwed tightly, and the solution allowed rising to room temperature. The reaction was stirred for $12 \mathrm{~h}$, and the solution was cool ed to $-78{ }^{\circ} \mathrm{C}$. The cap was removed, and the mixture risen to room temperature to remove ammonia. The solution was partitioned between $\mathrm{Et}_{2} \mathrm{O}(50 \mathrm{~mL})$ and $\mathrm{H}_{2} \mathrm{O}(50 \mathrm{~mL})$, the organic layer was dried $\left(\mathrm{MgSO}_{4}\right)$, and the solvent was removed in vacuo. The product was purified by flash column chromatography eluting with chloroform to give a colorless solid (1.25 g, 77\%). ${ }^{1} \mathrm{H}$ NMR (300 MHz, $\left.\mathrm{CDCl}_{3}\right): \delta 2.19(\mathrm{NH}, \mathrm{d}, 1 \mathrm{H}), 2.38$ $(\mathrm{s}, 3 \mathrm{H}), 2.74(\mathrm{NH}, \mathrm{d}, 2 \mathrm{H}), 7.22-7.24$ and $7.49-7.51\left(\mathrm{AA}^{\prime} \mathrm{BB}^{\prime}\right.$ system, $4 \mathrm{H}) .{ }^{13} \mathrm{C} \mathrm{NMR}\left(75 \mathrm{MHz} \mathrm{CDCl}_{3}\right): \delta 21.7,57.9$ (q, ${ }^{2} \mathrm{~J} \mathrm{CF}$ $=34.9), 125.0\left(q,{ }^{1} \mathrm{CF}=278.7, \mathrm{CF}_{3}\right), 129.3(2 \mathrm{C}), 129.7(2 \mathrm{C})$, 130.1, 140.0.

3-(4-Methylphenyl)-3-trifluoromethyldiazirine (11). ${ }^{48}$ Diaziridine 10 (1.25 g, $6.18 \mathrm{mmol})$ was dissolved in $\mathrm{CH}_{2} \mathrm{Cl}_{2}$ $(25 \mathrm{~mL})$, and triethylamine $(2.58 \mathrm{~mL}, 18.54 \mathrm{mmol})$ was added and cooled to $0{ }^{\circ} \mathrm{C}$. I lodine $(1.73 \mathrm{~g}, 6.80 \mathrm{mmol})$ was added in small portions until a brown color persisted. The solution was washed with $1 \mathrm{M} \mathrm{NaOH}(25 \mathrm{~mL}), \mathrm{H}_{2} \mathrm{O}(25 \mathrm{~mL})$, and brine $(25$ $\mathrm{mL})$. The organic phase was dried $\left(\mathrm{MgSO}_{4}\right)$, and the solvent was carefully removed in vacuo at $20^{\circ} \mathrm{C}$ due to volatility of the product. The crude product was purified by flash column chromatography eluting with hexane/ $\mathrm{CH}_{2} \mathrm{Cl}_{2}(20: 1)$ to give a colorless solid (1.03 g, 82\%). ${ }^{1} \mathrm{H}$ NMR (300 MHz, $\left.\mathrm{CDCl}_{3}\right): \delta$ $2.36(\mathrm{~s}, 3 \mathrm{H}), 7.07-7.10,7.19$ and 7.22 ( $\mathrm{AA}^{\prime} \mathrm{BB}^{\prime}$ system, $\left.4 \mathrm{H}\right)$. ${ }^{13} \mathrm{C} \mathrm{NMR}\left(100 \mathrm{MHz} \mathrm{CDCl}_{3}\right): \delta 21.5,28.9\left(\mathrm{q},{ }^{2} \mathrm{~J} \mathrm{CF}=39.6\right), 123.0$ $\left(q,{ }^{1}{ }_{C F}=274.7, C F_{3}\right), 125.5,127.1(2 C), 130.8(2 C), 141.1$.

3-(4-B romomethylphenyl)-3-trifluoromethyldiazirine (12). ${ }^{49} \mathrm{~A}$ solution of diazirine $11(0.50 \mathrm{~g}, 2.50 \mathrm{mmol})$ in $\mathrm{CCl}_{4}(10 \mathrm{~mL})$ was heated to $70^{\circ} \mathrm{C}$ and powdered NBS $(0.66 \mathrm{~g}$ $3.75 \mathrm{mmol}$ ) was added and stirred for $10 \mathrm{~min}$, then AIBN (10 $\mathrm{mg}$ ) was added, and the reaction was refluxed for $2 \mathrm{~h}$. The preci pitate was filtered, the solvent was removed in vacuo at $20^{\circ} \mathrm{C}$, and the crude product was purified by column chromatography eluting with hexane/ $\mathrm{CH}_{2} \mathrm{Cl}_{2}(20: 1)$ to give an oil $(0.30$ g, 40\%). ${ }^{1} \mathrm{H}$ NMR (400 MHz, $\left.\mathrm{CDCl}_{3}\right): \delta 4.50(\mathrm{~s}, 2 \mathrm{H}), 7.17-$ 7.23, 7.43 and 7.47 (AA'BB' system, 4H). ${ }^{13} \mathrm{C}$ NMR $(100 \mathrm{MHz}$, $\left.\mathrm{CDCl}_{3}\right): \delta 28.3\left(\mathrm{q},{ }^{2} \mathrm{~J} \mathrm{CF}=40.5\right), 39.7,122.2\left(\mathrm{q},{ }^{1} \mathrm{~J} \mathrm{CF}=275.0\right.$, $\left.\mathrm{CF}_{3}\right), 127.3(2 \mathrm{C}), 129.6,129.9(2 \mathrm{C}), 139.8$.

4-Azidotetrafluorobenzaldehyde (13). ${ }^{50}$ To a solution of pentafluorobenzal dehyde $(2.69 \mathrm{~g}, 13.72 \mathrm{mmol}$ ) in acetone (24 $\mathrm{mL})$ and $\mathrm{H}_{2} \mathrm{O}(9 \mathrm{~mL}), \mathrm{NaN}_{3}(1.06 \mathrm{~g}, 14.54 \mathrm{mmol})$ was added and the mixture was refluxed for $8 \mathrm{~h}$. The solution was cool ed to room temperature and diluted with $\mathrm{H}_{2} \mathrm{O}(20 \mathrm{~mL})$. The solution was extracted with ether $(3 \times 30 \mathrm{~mL})$, the organic phase was dried $\left(\mathrm{MgSO}_{4}\right)$, and the solvent was removed in vacuo. The maroon-colored gum was sublimed at $70{ }^{\circ} \mathrm{C}$ under reduced pressure to give a colorless solid $(1.80 \mathrm{~g}, 60 \%)$. ${ }^{19} \mathrm{~F}$ NMR (282 MHz, CDCl 3 ): $\delta-152.14(\mathrm{~m}, 2 \mathrm{~F}),-146.10(\mathrm{~m}, 2 \mathrm{~F})$.

4-Azidotetrafluorobenzyl Alcohol (14). ${ }^{50}$ 4-Azidotetrafluorobenzal dehyde $(\mathbf{1 3}, 1.80,8.21 \mathrm{mmol})$ was dissol ved in acetic acid $(27 \mathrm{~mL})$, and $\mathrm{Me}_{2} \mathrm{NH} \cdot \mathrm{BH}_{3}(0.58 \mathrm{~g}, 9.85 \mathrm{mmol})$ was added. The reaction was stirred at room temperature for $1 \mathrm{~h}$. The acid versatiles were removed in vacuo at $45^{\circ} \mathrm{C}$. The residue was dissolved in $\mathrm{CHCl}_{3}(10 \mathrm{~mL})$ and washed with $5 \% \mathrm{Na}_{2} \mathrm{CO}_{3}(3 \times$ $10 \mathrm{~mL}$ ). The organic phase was dried $\left(\mathrm{MgSO}_{4}\right)$, and the solvent was removed in vacuo to give a colorless solid (1.74 g, 97\%), which was used without further purification. ${ }^{1} \mathrm{H}$ NMR (300 $\left.\mathrm{MHz} \mathrm{CDCl}_{3}\right): \delta 2.41(\mathrm{OH}$, broad s, $1 \mathrm{H}), 4.79(\mathrm{~s}, 2 \mathrm{H}) .{ }^{19} \mathrm{~F} \mathrm{NMR}$ $\left(282 \mathrm{MHz}_{2} \mathrm{CDCl}_{3}\right): \delta-150.90(\mathrm{~m}, 2 \mathrm{~F}),-143.75(\mathrm{~m}, 2 \mathrm{~F})$.

1-Azido-4-(bromomethyl)-2,3,5,6-tetrafluorobenzene (15). ${ }^{51,52}$ Alcohol 14 (1.74 g, $\left.7.93 \mathrm{mmol}\right)$ was dissolved in a 
mixture of $\mathrm{CHCl}_{3}(40 \mathrm{~mL})$ and pyridine $(0.32 \mathrm{~mL}, 3.97 \mathrm{mmol})$. Three portions of $\mathrm{PBr}_{3}(3 \times 0.05 \mathrm{~mL}, 1.58 \mathrm{mmol})$ were added dropwise every $30 \mathrm{~min}$ to the refluxing sol ution. After the last portion of $\mathrm{PBr}_{3}$ was added, the reaction was refluxed for $2 \mathrm{~h}$. The solution was cooled to room temperature, 2-propanol (20 $\mathrm{mL}$ ) was added, and the reaction was stirred for an additional $10 \mathrm{~min}$. The solution was washed with $1 \mathrm{~N} \mathrm{NaHCO} 3(3 \times 50$ $\mathrm{mL})$ and dried $\left(\mathrm{MgSO}_{4}\right)$, and the solvent was removed in vacuo to give a white solid. The crude product was purified by flash column chromatography eluting with hexane/ethyl acetate (8: 1 ) to give a slightly yellow solid (1.20 g, 53\%). ${ }^{1} \mathrm{H}$ NMR (300 $\left.\mathrm{MHz}_{2} \mathrm{CDCl}_{3}\right): \delta 4.51(\mathrm{~s}, 2 \mathrm{H}) .{ }^{19} \mathrm{~F} \mathrm{NMR}\left(282, \mathrm{MHz}_{1} \mathrm{CDCl}_{3}\right): \delta$ $-150.50(\mathrm{~m}, 2 \mathrm{~F}),-141.80(\mathrm{~m}, 2 \mathrm{~F})$.

Synthesis of 16-21. General Synthetic Procedure. GB (2) or GC (3) $(0.07 \mathrm{mmol})$ was dissolved in THF (4 mL), and $\mathrm{KH}(0.008 \mathrm{~g}, 0.24 \mathrm{mmol})$ was added at room temperature. The reaction mixture was stirred for $10 \mathrm{~min}$, and then, a solution of 4-(bromomethyl)benzophenone, $\mathbf{1 2}$, or $\mathbf{1 5}(0.212 \mathrm{mmol}$ ) in THF (1 mL) was added dropwise. The reaction was stirred at room temperature for $4 \mathrm{~h}$. The solution was then cooled to 0 ${ }^{\circ} \mathrm{C}$, and concentrated $\mathrm{HCl}(0.3 \mathrm{~mL})$ was added. The mixture was diluted with $\mathrm{H}_{2} \mathrm{O}(10 \mathrm{~mL})$, extracted with EtOAc $(3 \times 10$ $\mathrm{mL}$ ), and washed with saturated aqueous $\mathrm{NH}_{4} \mathrm{Cl}$ solution (30 $\mathrm{mL})$, brine $(30 \mathrm{~mL})$, and $\mathrm{H}_{2} \mathrm{O}(30 \mathrm{~mL})$. The organic phase was dried $\left(\mathrm{MgSO}_{4}\right)$, and the solvent was removed in vacuo. The crude material was purified by flash column chromatography using either $\mathrm{A}$ : $\mathrm{CHCl}_{3} / \mathrm{MeOH}$ (100:1 and 50:1), $\mathrm{B}: \mathrm{CHCl}_{3} /$ $\mathrm{MeOH}$ (30:1 and 20:1), or C: cyclohexane/acetone (3:1 and 2:1). All ginkgolide derivatives were white solids that decomposed above $250{ }^{\circ} \mathrm{C}$.

10-0-Benzophenone Ginkgolide B (16). Purified by method B; yield, $0.035 \mathrm{~g}(78 \%)$. ${ }^{1} \mathrm{H} N \mathrm{NMR}\left(400 \mathrm{MHz}, \mathrm{CD}_{3} \mathrm{OD}\right)$ : $\delta 1.13$ (s, tert-butyl), $1.24\left(\mathrm{~d}, \mathrm{~J}=7.1, \mathrm{CH}_{3}\right), 1.92(\mathrm{dd}, \mathrm{J}=14.3$, 4.5, 8-H), $2.07(\mathrm{td}, \mathrm{J}=13.9,4.4,7 \alpha-\mathrm{H}), 2.27(\mathrm{dd}, \mathrm{J}=13.5$, 4.6, $7 \beta-\mathrm{H}), 3.06(\mathrm{q}, \mathrm{J}=7.1,14-\mathrm{H}), 4.31(\mathrm{~d}, \mathrm{~J}=7.2,1-\mathrm{H}), 4.55$ $(\mathrm{d}, \mathrm{J}=7.2,2-\mathrm{H}), 4.85(\mathrm{~d}, \mathrm{~J}=11.5$, benzylic-H, $1 \mathrm{H}), 5.28(\mathrm{~s}$, $10-\mathrm{H}), 5.42(\mathrm{~d}, \mathrm{~J}=4.0,6-\mathrm{H}), 5.59(\mathrm{~d}, \mathrm{~J}=11.5$, benzylic- $\mathrm{H}$, $1 \mathrm{H}), 6.15(\mathrm{~s}, 12-\mathrm{H}), 7.53-7.60(\mathrm{~m}, \mathrm{Ar}-\mathrm{H}, 4 \mathrm{H}), 7.65-7.67(\mathrm{~m}$, $\mathrm{Ar}-\mathrm{H}, \mathrm{lH}), 7.77-7.82(\mathrm{~m}, \mathrm{Ar}-\mathrm{H}, 4 \mathrm{H}) .{ }^{13} \mathrm{C} N M R(100 \mathrm{MHz}$, $\mathrm{CD}_{3} \mathrm{OD}$ ): $\delta 7.25,28.46$ (3C), 32.18, 37.26, 42.29, 49.61, 68.21, $72.59,72.80,74.45,76.76,79.48,83.53,93.15,99.78,110.83$, $127.96(2 \mathrm{C}), 128.58(2 \mathrm{C}), 130.03(2 \mathrm{C}), 130.52(2 \mathrm{C}), 132.94$ 137.76 (2C), 141.67, 171.52, 172.70, 177.33, 196.45. HPLCUV: $98.5 \%$. HRMS: $\mathrm{C}_{34} \mathrm{H}_{34} \mathrm{O}_{11}$ requires $\mathrm{M}+\mathrm{Na}$ at $\mathrm{m} / \mathrm{z}$ 641.1999; found, 641.2018.

10-O-Benzophenone Ginkgolide C (17). Purified by method A; yield, $0.023 \mathrm{~g}(64 \%)$. ${ }^{1} \mathrm{H} N M R\left(400, \mathrm{MHz} \mathrm{CD}_{3} \mathrm{OD}\right)$ : $\delta 1.20$ (s, tert-butyl), $1.24\left(\mathrm{~d}, \mathrm{~J}=7.1, \mathrm{CH}_{3}\right), 1.78(\mathrm{~d}, \mathrm{~J}=12.5$, $8-\mathrm{H}), 3.04(\mathrm{q}, \mathrm{J}=7.1,14-\mathrm{H}), 4.21(\mathrm{dd}, \mathrm{J}=12.5,4.3,7-\mathrm{H}), 4.28$ $(d, J=7.0,1-H), 4.54(d, J=7.0,2-H), 4.87(d, J=11.6$, benzylic-H, $1 \mathrm{H}), 5.13(\mathrm{~d}, \mathrm{~J}=4.3,6-\mathrm{H}), 5.28(\mathrm{~s}, 10-\mathrm{H}), 5.60(\mathrm{~d}$, $\mathrm{J}=11.6$, benzylic-H, $1 \mathrm{H}), 6.17(\mathrm{~s}, 12-\mathrm{H}) 7.53-7.61(\mathrm{~m}, \mathrm{Ar}-\mathrm{H}$, $4 \mathrm{H}), 7.65-7.67(\mathrm{~m}, \mathrm{Ar}-\mathrm{H}, 1 \mathrm{H}), 7.77-7.83(\mathrm{~m}, \mathrm{Ar}-\mathrm{H}, 4 \mathrm{H}) .{ }^{13} \mathrm{C}$ NMR (100 MHz, CD $\left.{ }_{3} \mathrm{OD}\right): \delta 7.34,28.50$ (3C), 32.12, 42.26, $50.00,64.48,67.40,72.77,74.28,75.14,76.74,79.49,83.55$, $93.28,99.54,110.63,127.95$ (2C), 128.59 (2C), 130.03 (2C), 130.53 (2C), 132.96, 137.68 (2C), 141.65, 171.41, 172.55, 177.27, 197.03. HPLC-UV: 99.3\%. HRMS: $\mathrm{C}_{34} \mathrm{H}_{34} \mathrm{O}_{12}$ requires $M+1$ at $\mathrm{m} / \mathrm{z}$ 635.2129; found, 635.2098.

10-0-(Trifluoromethyl-3H-diazirine)benzyl Ginkgolide B (18). Purified by method B; yield, $0.024 \mathrm{~g}(59 \%)$. ${ }^{1} \mathrm{H}$ NMR (400 M Hz, CD ${ }_{3} \mathrm{OD}$ ): $\delta 1.11$ (s, tert-butyl), 1.23 (d, $\mathrm{J}=7.1, \mathrm{CH}_{3}$ ), $1.89(\mathrm{dd}, \mathrm{J}=14.3,4.3,8-\mathrm{H}), 2.01(\mathrm{td}, \mathrm{J}=13.9,4.3,7 \alpha-\mathrm{H})$, $2.25(\mathrm{dd}, \mathrm{J}=13.4,4.4,7 \beta-\mathrm{H}), 3.05(\mathrm{q}, \mathrm{J}=7.1,14-\mathrm{H}), 4.27(\mathrm{~d}$, $\mathrm{J}=7.3,1-\mathrm{H}), 4.53(\mathrm{~d}, \mathrm{~J}=7.3,2-\mathrm{H}), 4.77(\mathrm{~d}, \mathrm{~J}=11.2$, benzylic$\mathrm{H}, 1 \mathrm{H}), 5.24(\mathrm{~s}, 10-\mathrm{H}), 5.39(\mathrm{~d}, \mathrm{~J}=3.9,6-\mathrm{H}), 5.51(\mathrm{~d}, \mathrm{~J}=11.2$, benzylic-H , $1 \mathrm{H}$ ), 6.14 (s, 12-H), 7.29 and 7.53 (AA'BB' system, $\mathrm{Ar}-\mathrm{H}, 4 \mathrm{H}) .{ }^{13} \mathrm{C}$ NMR $\left(75 \mathrm{MHz}, \mathrm{CDCl}_{3}\right): \delta 7.67,21.57\left(\mathrm{q},{ }^{2} \mathrm{~J} \mathrm{CF}\right.$ $\left.=40.9, \mathrm{CCF}_{3}\right), 29.56$ (3C), 32.65, 37.49, 49.31, 68.07, 72.88, 73.57, 74.57, 76.56, 77.65, 80.08, 83.90, 90.90, 99.05, 110.68, $122.33\left(\mathrm{q},{ }^{1} \mathrm{CF}_{\mathrm{CF}}=274.3, \mathrm{CF}_{3}\right), 127.83(2 \mathrm{C}), 129.53(2 \mathrm{C}), 131.06$, 136.44, 171.25, 171.50, 175.87. ${ }^{19} \mathrm{~F}$ NMR (282 $\left.\mathrm{MHz}_{1} \mathrm{CDCl}_{3}\right)$ : $\delta-66.23$ (s, 3F). HPLC-UV: 99.1\%. HRMS: $\mathrm{C}_{29} \mathrm{H}_{29} \mathrm{~F}_{3} \mathrm{~N}_{2} \mathrm{O}_{10}$ requires $M+1$ at $m / z$ 623.1853; found, 623.1834.
10-0-(Trifluoromethyl-3H-diazirine)benzyl Ginkgolide C (19). Purified by method A; yield, $0.023 \mathrm{~g}(51 \%) .{ }^{1} \mathrm{H}$ NMR (400 MHz, CD $\left.\mathrm{M}_{3} \mathrm{OD}\right): \delta 1.17$ (s, tert-butyl), $1.24(\mathrm{~d}, \mathrm{~J}=7.1$, $\mathrm{CH}_{3}$ ), $1.76(\mathrm{~d}, \mathrm{~J}=12.5,8-\mathrm{H}), 3.02(\mathrm{q}, \mathrm{J}=7.1,14-\mathrm{H}), 4.15$ (dd, $J=12.5,4.3,7-\mathrm{H}) 4.24(\mathrm{~d}, \mathrm{~J}=7.0,1-\mathrm{H}), 4.52(\mathrm{~d}, \mathrm{~J}=7.0$, 2-H), $4.79(\mathrm{~d}, \mathrm{~J}=11.3$, benzylic- $\mathrm{H}, 1 \mathrm{H}), 5.10(\mathrm{~d}, \mathrm{~J}=4.3,6-\mathrm{H})$, $5.23(\mathrm{~s}, 10-\mathrm{H}), 5.52(\mathrm{~d}, \mathrm{~J}=11.3$, benzylic-H, $1 \mathrm{H}), 6.15(\mathrm{~s}, 12-$ $\mathrm{H}), 7.29$ and 7.54 (AA'BB' system, aromatic-H, $4 \mathrm{H}$ ). ${ }^{13} \mathrm{C}$ NMR $\left(75 \mathrm{MHz} \mathrm{CDCl}_{3}\right): \delta 7.65,23.77\left(\mathrm{q},{ }^{2} \mathrm{~J}_{\mathrm{CF}}=38.9, \mathrm{CCF}_{3}\right), 29.52$ (3C), 32.65, 41.94, 50.92, 64.43, 67.48, 73.89, 74.30, 76.03, $76.34,79.63,83.90,90.91,98.94,110.53,122.32\left(\mathrm{q},{ }^{1} \mathrm{j} \mathrm{cF}=\right.$ 275.0, $\left.\mathrm{CF}_{3}\right), 127.94(2 \mathrm{C}), 129.68(2 \mathrm{C}), 131.26,136.07,170.97$, 171.07, 175.69. ${ }^{19} \mathrm{~F}$ NMR (282 $\left.\mathrm{MHz} \mathrm{CDCl}_{3}\right): \delta-66.25$ (s, 3F). HPLC-UV: $97.9 \%$. HRMS: $\mathrm{C}_{29} \mathrm{H}_{29} \mathrm{~F}_{3} \mathrm{~N}_{2} \mathrm{O}_{11}$ requires $\mathrm{M}+1$ at $\mathrm{m} / \mathrm{z}$ 639.1802; found, 639.1790 .

10-0-Tetrafluorobenzyl Azide Ginkgolide B (20). Purified by method B; yield, $0.023 \mathrm{~g} \mathrm{(50 \% ).}{ }^{1 \mathrm{H}} \mathrm{NMR}(400 \mathrm{MHz}$, $\left.\mathrm{CDCl}_{3}\right): \delta 1.13\left(\mathrm{~s}\right.$, tert-butyl), $1.32\left(\mathrm{~d}, \mathrm{~J}=7.0, \mathrm{CH}_{3}\right), 1.84-$ $1.97(\mathrm{~m}, 8-\mathrm{H}$ and $7 \alpha-\mathrm{H}), 2.27-2.33(\mathrm{~m}, 7 \beta-\mathrm{H}), 2.84(\mathrm{~d}, \mathrm{~J}=3.5$, $1-\mathrm{OH}), 2.99(\mathrm{~s}, 3-\mathrm{OH}), 3.06(\mathrm{q}, \mathrm{J}=7.0,14-\mathrm{H}), 4.29(\mathrm{dd}, \mathrm{J}=$ $7.9,3.5,1-\mathrm{H}), 4.61(\mathrm{~d}, \mathrm{~J}=7.9,2-\mathrm{H}), 4.81(\mathrm{~d}, \mathrm{~J}=10.7$, benzylic$\mathrm{H}, 1 \mathrm{H}), 4.94(\mathrm{~s}, 10-\mathrm{H}), 5.39(\mathrm{~d}, \mathrm{~J}=3.4,6-\mathrm{H}), 5.64(\mathrm{~d}, \mathrm{~J}=10.7$, benzylic-H, $1 \mathrm{H}), 6.03(\mathrm{~s}, 12-\mathrm{H}) .{ }^{13} \mathrm{C}$ NMR (100 MHz, CDCl 3 ): $\delta$ 7.70, 29.52 (3C), 32.62, 37.37, 42.03, 49.30, 61.21, 68.11, $72.79,74.65,80.07,83.89,91.00,99.12,108.95,110.73,139.71$, $142.24,144.45,147.10,170.69,171.45,175.83 .{ }^{19} \mathrm{~F}$ NMR $(282$ $\left.\mathrm{MHz}, \mathrm{CDCl}_{3}\right): \delta-143.31(\mathrm{~m}, 2 \mathrm{~F}),-150.85(\mathrm{~m}, 2 \mathrm{~F})$. HPLC UV: $98.8 \%$. HRMS: $\mathrm{C}_{27} \mathrm{H}_{25} \mathrm{~F}_{4} \mathrm{~N}_{3} \mathrm{O}_{10}$ requires $\mathrm{M}+1$ at $\mathrm{m} / \mathrm{z}$ 628.1554; found, 628.1565.

10-0-Tetrafluorobenzyl Azide Ginkgolide C (21). Purified by method C; yield, $0.080 \mathrm{~g}(54 \%)$. ${ }^{1} \mathrm{H}$ NMR $(400 \mathrm{MHz}$, $\left.\mathrm{CDCl}_{3}\right): \delta 1.22\left(\mathrm{~s}\right.$, tert-butyl), $1.33\left(\mathrm{~d}, \mathrm{~J}=7.0, \mathrm{CH}_{3}\right), 1.71(\mathrm{~d}$, $J=12.4,8-H), 2.33(\mathrm{~d}, \mathrm{~J}=10.6,7-\mathrm{OH}), 2.88(\mathrm{~d}, \mathrm{~J}=3.4,1-\mathrm{OH})$, $3.01(\mathrm{~s}, 3-\mathrm{OH}), 3.08(\mathrm{q}, \mathrm{J}=7.0,14-\mathrm{H}), 4.08(\mathrm{~m}, 7-\mathrm{H}) 4.27$ (dd, $\mathrm{J}=7.8,3.4,1-\mathrm{H}), 4.62(\mathrm{~d}, \mathrm{~J}=7.8,2-\mathrm{H}), 4.83(\mathrm{~d}, \mathrm{~J}=10.7$, benzylic-H, 1H), $4.96(\mathrm{~s}, 10-\mathrm{H}), 5.09(\mathrm{~d}, \mathrm{~J}=4.4,6-\mathrm{H}), 5.58(\mathrm{~d}$, $\mathrm{J}=10.7$, benzylic-H, $1 \mathrm{H}), 6.04(\mathrm{~s}, 12-\mathrm{H}) \cdot{ }^{13} \mathrm{C} \mathrm{NMR}(75 \mathrm{MHz}$, $\left.\mathrm{CDCl}_{3}\right): \delta 7.64,29.42(3 \mathrm{C}), 32.59,42.08,50.64,51.16,61.47$, 64.35, 67.32, 74.27, 75.88, 79.64, 83.88, 91.26, 99.14, 110.71, $120-150(\mathrm{~m}, 6 \mathrm{C}), 170.72,171.17,176.29 .{ }^{19} \mathrm{~F} N M R(282 \mathrm{MHz}$, $\left.\mathrm{CDCl}_{3}\right): \delta-143.56(\mathrm{~m}, 2 \mathrm{~F}),-151.08(\mathrm{~m}, 2 \mathrm{~F})$. HPLC-UV: 99.1\%. HRMS: $\mathrm{C}_{27} \mathrm{H}_{25} \mathrm{~F}_{4} \mathrm{~N}_{3} \mathrm{O}_{11}$ requires $\mathrm{M}+1$ at $\mathrm{m} / \mathrm{z}$ 644.1503; found, 644.1527

10-0-Benzoylbenzoic Ginkgolide C (22). 4-Benzoyl benzoic acid $(0.018 \mathrm{~g}, 0.08 \mathrm{mmol})$ and $\mathbf{2}(0.028 \mathrm{~g}, 0.07 \mathrm{mmol})$ were dissolved in THF $(5 \mathrm{~mL})$, and the mixture was cooled to $0{ }^{\circ} \mathrm{C}$. $\operatorname{EDC}(0.018 \mathrm{~g}, 0.092 \mathrm{mmol})$ and DMAP $(0.002 \mathrm{~g}, 0.01 \mathrm{mmol})$ were added, and the reaction mixture was stirred at $0{ }^{\circ} \mathrm{C}$ for $1 \mathrm{~h}$ and continued overnight at room temperature. The solvent was removed in vacuo, and the crude product was dissolved in EtOAc $(20 \mathrm{~mL})$ and washed with a saturated $5 \% \mathrm{NaHCO}_{3}$ solution $(20 \mathrm{~mL})$ and brine $(20 \mathrm{~mL})$. The organic fraction was dried $\left(\mathrm{MgSO}_{4}\right)$, and the solvent was evaporated in vacuo. The crude product was purified by flash column chromatography eluting with hexane/E tOAc (2:1) to give the product as white crystals $(0.026 \mathrm{~g}, 62 \%)$. ${ }^{1} \mathrm{H}$ NMR $\left(400 \mathrm{MHz}, \mathrm{CD}_{3} \mathrm{OD}\right): \delta 1.07$ (s, tert-butyl), $1.26\left(\mathrm{~d}, \mathrm{~J}=7.1, \mathrm{CH}_{3}\right), 1.98-2.10(\mathrm{~m}, 8-\mathrm{H}$ and $7 \alpha-\mathrm{H}), 2.30-2.36(\mathrm{~m}, 7 \beta-\mathrm{H}), 3.12(\mathrm{q}, \mathrm{J}=7.1,14-\mathrm{H}), 4.37(\mathrm{~d}, \mathrm{~J}$ $=6.5,1-\mathrm{H}), 4.55(\mathrm{~d}, \mathrm{~J}=6.5,2-\mathrm{H}), 5.66(\mathrm{~d}, \mathrm{~J}=3.2,6-\mathrm{H}), 6.32$ (s, 10-H), $6.45(\mathrm{~s}, 12-\mathrm{H}), 7.54-7.58(\mathrm{~m}, \mathrm{Ar}-\mathrm{H}, 2 \mathrm{H}), 7.67-7.69$ $(\mathrm{m}, \mathrm{Ar}-\mathrm{H}, \mathrm{HH}), 7.80-7.83(\mathrm{~m}, \mathrm{Ar}-\mathrm{H}, 2 \mathrm{H}), 7.86-7.88(\mathrm{~m}, \mathrm{Ar}-$ $\mathrm{H}, 2 \mathrm{H}), 8.42-8.44(\mathrm{~m}, \mathrm{Ar}-\mathrm{H}, 2 \mathrm{H}) .{ }^{13} \mathrm{C} \mathrm{NMR}\left(100 \mathrm{MHz}, \mathrm{CD}_{3-}\right.$ OD): $\delta 7.42,28.22(3 C), 32.16,37.27,42.29,49.42,67.81,70.64$, $72.74,74.42,79.29,83.64,95.13,100.51,111.12,128.73(2 \mathrm{C})$, 129.92 (2C), 130.17 (2C), 130.58 (2C), 131.61, 133.41, 137.06, 142.66, 164.56, 168.93, 171.41, 177.33, 196.48. HPLC-UV: 99.2\%. HRMS: $\mathrm{C}_{34} \mathrm{H}_{31} \mathrm{O}_{12}$ requires $\mathrm{M}+\mathrm{Na}$ at $\mathrm{m} / \mathrm{z} 655.1791$; found, 655.1790.

10-0-Benzophenone-7-O-dansyl Ginkgolide C (23). A solution of dansyl chloride $(0.010 \mathrm{~g}, 0.035 \mathrm{mmol})$ in acetonitrile $(0.3 \mathrm{~mL})$ was added to a solution of $17(0.020 \mathrm{~g}, 0.032 \mathrm{mmol})$ and DMAP $(0.008 \mathrm{~g}, 0.063 \mathrm{mmol})$ in acetonitrile $(1.5 \mathrm{~mL})$. The reaction mixture was stirred for $16 \mathrm{~h}$ at room temperature, then a saturated aqueous $\mathrm{NH}_{4} \mathrm{Cl}$ solution $(2 \mathrm{~mL})$ was added, 
and the mixture was extracted with EtOAc $(3 \times 5 \mathrm{~mL})$. The combined organic phase was washed with saturated aqueous $\mathrm{NaCl}$ solution $(3 \times 15 \mathrm{~mL})$, dried $\left(\mathrm{MgSO}_{4}\right)$, and the solvent was removed in vacuo. The crude product was purified by flash column chromatography eluting with cyclohexane/acetone (2: 1 ) to give the product as a slightly yellow solid $(0.015 \mathrm{~g}, 56 \%)$. ${ }^{1} \mathrm{H}$ NMR (400 MHz, DMSO- $\mathrm{d}_{6}$ ): $\delta 0.83$ (s, tert-butyl), 1.09 (d, $\left.J=7.2, \mathrm{CH}_{3},\right), 1.94(\mathrm{~d}, \mathrm{~J}=12.5,8-\mathrm{H}), 2.81[\mathrm{~m}, 14-\mathrm{H}$ and $\left.\mathrm{N}\left(\mathrm{CH}_{3}\right)_{2}\right], 4.26(\mathrm{t}, \mathrm{J}=5.3,1-\mathrm{H}), 4.53(\mathrm{~d}, \mathrm{~J}=5.4,2-\mathrm{H}), 4.79(\mathrm{~d}$, $\mathrm{J}=13.2$, benzylic- $\mathrm{H}, 1 \mathrm{H}), 4.89(\mathrm{dd}, \mathrm{J}=12.5,4.0,7-\mathrm{H}), 5.19$ $(\mathrm{d}, \mathrm{J}=4.0,6-\mathrm{H}), 5.23(\mathrm{~s}, 10-\mathrm{H}), 5.46(\mathrm{~d}, \mathrm{~J}=13.2$, benzylic- $\mathrm{H}$, $1 \mathrm{H}), 6.07(\mathrm{~d}, \mathrm{~J}=5.3,1-\mathrm{OH}), 6.21(\mathrm{~s}, 12-\mathrm{H}), 6.51(\mathrm{~s}, 3-\mathrm{OH})$, 7.28-7.30 (m, Ar-H, 1H), 7.50-7.70 (m, Ar-H, 7H), 7.79$7.82(\mathrm{~m}, \mathrm{Ar}-\mathrm{H}, 4 \mathrm{H}), 8.18-8.20(\mathrm{~m}, \mathrm{Ar}-\mathrm{H}, 2 \mathrm{H}), 8.54-8.56(\mathrm{~m}$, $\mathrm{Ar}-\mathrm{H}, \mathrm{1H}$ ). HPLC-UV: 98.9\%. HRMS: $\mathrm{C}_{46} \mathrm{H}_{45} \mathrm{NO}_{14} \mathrm{~S}$ requires $M+1$ at $m / z$ 868.2639; found, 868.2642.

10-0-benzophenone-1-O-dansyl Ginkgolide C (24). Synthesized as $\mathbf{2 3}$ but using 2 equiv of dansyl chloride (instead of $\mathbf{1 . 1}$ equiv) gave rise to a ca. $\mathbf{1 : 1}$ mixture of $\mathbf{2 3}$ and $\mathbf{2 4}$. The two products were separated on analytical TLC giving 24 (0.008 $\mathrm{g}, 30 \%)$ as a slightly yellow solid. ${ }^{1} \mathrm{H}$ NMR (400 MHz, DMSO$\left.\mathrm{d}_{6}\right): \delta 0.91$ (s, tert-butyl), $1.16\left(\mathrm{~d}, \mathrm{~J}=7.6, \mathrm{CH}_{3}\right), 1.78(\mathrm{~d}, \mathrm{~J}=$ $12.5,8-\mathrm{H}), 2.80\left[\mathrm{~s}, \mathrm{~N}\left(\mathrm{CH}_{3}\right)_{2}\right], 2.97(\mathrm{q}, \mathrm{J}=7.6,14-\mathrm{H}), 4.22(\mathrm{~d}, \mathrm{~J}$ $=3.8,1-\mathrm{H}), 4.26(\mathrm{~m}, 7-\mathrm{H}), 4.57(\mathrm{~d}, \mathrm{~J}=3.9,6-\mathrm{H}), 4.80(\mathrm{~d}, \mathrm{~J}=$ 13.2, benzylic-H, $1 \mathrm{H}), 5.20(\mathrm{~d}, \mathrm{~J}=3.8,2-\mathrm{H}), 5.30(\mathrm{~s}, 10-\mathrm{H})$, $5.31(\mathrm{~d}, \mathrm{~J}=4.9,7-\mathrm{OH}), 5.49(\mathrm{~d}, \mathrm{~J}=13.2$, benzylic- $\mathrm{H}, 1 \mathrm{H})$, $5.95(\mathrm{~s}, 12-\mathrm{H}), 5.98(\mathrm{~s}, 3-\mathrm{OH}), 7.25-7.27(\mathrm{~m}, \mathrm{Ar}-\mathrm{H}, 1 \mathrm{H}), 7.54-$ $7.79(\mathrm{~m}, \mathrm{Ar}-\mathrm{H}, 1 \mathrm{H}), 8.18-8.24(\mathrm{~m}, \mathrm{Ar}-\mathrm{H}, 2 \mathrm{H}), 8.47-8.49$ (m, $\mathrm{Ar}-\mathrm{H}, 1 \mathrm{H})$. HPLC-UV: $99.0 \%$. HRMS: $\mathrm{C}_{46} \mathrm{H}_{45} \mathrm{NO}_{14} \mathrm{~S}$ requires $M+1$ at $m / z$ 868.2639; found, 868.2668 .

Radioligand Binding Assay. Heart and skel etal muscles from 13 to 27 months old PAF R transgenic (PAF R-Tg) mice, ${ }^{62}$ which overexpress guinea pig PAFR, were homogenized in a Polytron homogenizer in cold buffer A [25 mM Hepes/ $\mathrm{NaOH}$ (pH 7.4), $0.25 \mathrm{M}$ sucrose, $10 \mathrm{mM} \mathrm{MgCl}, 1 \mathrm{mM} \mathrm{PMSF}$, and a protease inhibitor cocktail Complete (Boehringer Mannheim)]. An $800 \mathrm{~g}$ (for $10 \mathrm{~min}$ ) supernatant of the homogenate was centrifuged at $100000 \mathrm{~g}$ at $4^{\circ} \mathrm{C}$ for $1 \mathrm{~h}$, and the resulting pellet was suspended in buffer $A$ and stored at $-80{ }^{\circ} \mathrm{C}$ until use. The protein concentration of the suspended membrane fraction was $1.37 \mathrm{mg} / \mathrm{mL}$, as measured by the method of Bradford ${ }^{63}$ using the Bio-Rad protein assay solution and fatty acid-free bovine serum albumin (BSA; Bayer, Kankakee, IL) as a standard. The radioligand binding assays were performed essentially as previously described. ${ }^{53}$ The membrane fractions from hearts and skeletal muscles of PAFR-Tg mice $(50 \mu \mathrm{L}$ of suspension containing $121 \mathrm{fmol}$ of PAFR) were mixed with 2 pmol of [ ${ }^{3} \mathrm{H}$ ]WEB 2086 (NEN Life Science Products, Boston, $\mathrm{MA}$ ) in $50 \mu \mathrm{L}$ of buffer $\mathrm{B}$ [25 mM Hepes/ $\mathrm{NaOH}$ (pH 7.4), 0.25 $\mathrm{M}$ sucrose, $10 \mathrm{mM} \mathrm{MgCl} 2,0.1 \% \mathrm{BSA}]$, and the compound was to be tested in $100 \mu \mathrm{L}$ of buffer $\mathrm{B}$ in a 96 well microplate in triplicate for each concentration. These mixtures were incubated at $25^{\circ} \mathrm{C}$ for $90 \mathrm{~min}$, upon which the receptor-bound $\left[{ }^{3} \mathrm{H}\right]-$ WEB 2086 was filtered on a UniFilter-GF/C (Packard Bioscience, Meriden, CT) using a MicroMate 196 simultaneous 96 well harvester (Packard Bioscience). The filter was then washed 10 times with cold buffer $\mathrm{B}$ and dried at $50{ }^{\circ} \mathrm{C}$ for at least $90 \mathrm{~min}, 25 \mu \mathrm{L}$ of MicroScint-0 scintillation cocktail (Packard Bioscience) was added, and filters were placed in a TopCount microplate scintillation counter (Packard Bioscience). Binding data were analyzed with the nonlinear curvefitting program Microplate Manager III (Bio-Rad, Hercules, $C A)$. Calculated $I C_{50}$ values were then converted to $K_{i}$ values using the Cheng-Prusoff correction, ${ }^{64}$ with the following equation: $\mathrm{K}_{\mathrm{i}}=\mathrm{IC}_{50} /\left(1+[\mathrm{L}] / \mathrm{K}_{\mathrm{D}}\right)$, where $[\mathrm{L}]$ is the concentration of the radioligand, and $K_{D}$ is the previously determined dissociation constant for [ ${ }^{3} \mathrm{H}$ ]WE B $2086(4.3 \mathrm{nM}) .{ }^{53}$ N onspecific binding was determined using methods as previously described. 53

Intracellular Calcium Mobilization. $\mathrm{CHO}$ cells expressing human PAFR ${ }^{57}$ were subjected to the calcium assay as described previously ${ }^{56}$ except that Fura-2/AM was loaded in the presence of chromophore EL $(0.01 \%$, Sigma). Each com- pound (100 $\mu \mathrm{M})$ was applied to the cell suspension, and then, PAF (10 nM) was added after $3 \mathrm{~min}$.

Acknowledgment. Weare grateful to Dr. Yasuhiro Itagaki for performing HRMS. We thank the Alfred Benzon Foundation (to K.S.) and the NSF REU program (CHE 9820490, to D.R.S., Beloit College, Beloit, WI ) for financial support.

\section{References}

(1) Drieu, K.; J aggy, H. History, development and constituents of EGb 761. In Medicinal and Aromatic Plants-Industrial Profiles: Ginkgo biloba; van Beek, T. A., Ed.; Harwood Academic Publishers: Amsterdam, 2000; Vol. 12, pp 267-277.

(2) Hasler, A. Chemical constituents of Ginkgo biloba. In Medicinal and Aromatic Plants-Industrial Profiles: Ginkgo biloba; van Beek, T. A., Ed.; Harwood Academic Publishers: Amsterdam, 2000; Vol. 12, pp 109-142.

(3) Nakanishi, K. The ginkgolides. PureAppl. Chem. 1967, 14, 89113 and references therein.

(4) Okabe, K.; Yamada, K.; Yamamura, S.; Takada, S. Ginkgolides. J. Chem. Soc. C 1967, 2201-2206.

(5) Nakanishi, K.; Habaguchi, K.; Nakadaira, Y.; Woods, M. C.; Maruyama, M.; Major, R. T.; Alauddin, M.; Patel, A. R.; Weinges, K.; Bähr, W. Structure of bilobalide, a rare tert-butyl containing seuqiterpenoid related to the $\mathrm{C}_{20}$-ginkgolides. J . Am. Chem. Soc. 1971, 93, 3544-3546.

(6) Weinges, K.; Hepp, M.; J aggy, H. Chemie der Ginkgolide, II. Isolierung und Strukturaufklärung eines neuen Ginkgolids Liebigs Ann. Chem. 1987, 521-526.

(7) DeFeudis, F. V.; Drieu, K. Ginkgo biloba extract (E Gb 761) and CNS functions: basic studies and clinical applications Curr. Drug Targets 2000, 1, 25-58.

(8) Logani, S.; Chen, M. C.; Tran, T.; Le, T.; Raffa, R. B. Actions of Ginkgo biloba related to potential utility for the treatment of conditions involving cerebral hypoxia. LifeSci. 2000, 67, 13891396.

(9) Oken, B. S.; Storzbach, D. M.; Kaye, J. A. The efficacy of Ginkgo biloba on cognitive function in alzheimer disease. Arch. Neurol. 1998, 55, 1409-1415.

(10) Kleijnen, J .; Knipschild, P. Ginkgo biloba. Lancet 1992, 340, 1136-1139.

(11) Søholm, B. Clinical improvement of memory and other cognitive functions by Ginkgo biloba: review of relevant literature. Adv. Nat. Ther. 1998, 15, 54-65.

(12) Diamond, B. J .; Shiflett, S. C.; Feiwel, N.; Mathies, R. J .; Noskin, O.; Richards, J . A.; Schoenberger, N. E. Ginkgo biloba extract: mechanisms and clinical indications. Arch. Phys. Med. Rehabil. 2000, 81, 668-678.

(13) van Dongen, M. C. J . M.; van Rossum, E.; Knipschild, P. Efficacy of Ginkgo biloba special extracts - evidence from randomized clinical trials. In Medicinal and Aromatic Plants-Industrial Profiles: Ginkgo biloba; van Beek, T. A., Ed.; Harwood Academic Publishers: Amsterdam, 2000; Vol. 12, pp 385-442.

(14) Le Bars, P. L.; Katz, M. M.; Berman, N.; Itil, T. M.; Freedman, A. M.; Schatzberg, A. F. A placebo-controlled double-blind, randomized trial of an extract of Ginkgo biloba for dementia. North American E Gb study group. J . Am. Med. Assoc. 1997, 278 1327-1332.

(15) Kanowski, S.; Hermann, W. M.; Stephan, K.; Wierich, W.; Horr R. Proof of efficacy of Ginkgo biloba special extract EGb 761 in outpatients suffering from mild to moderate primary degenerative dementia of the Alzheimer type or multi-infarct dementia. Pharmacopsychiatry 1996, 29, 47-56.

(16) Watanabe, M. H.; Wolffram, S.; Ader, P.; Rimbach, G.; Packer, L.; Maguire, J. J .; Schultz, P. G.; Gohil, K. The in vivo neuromodulatory effects of the herbal medicine Ginkgo biloba. Proc. Natl. Acad. Sci. U.S.A. 2001, 98, 6577-6580.

(17) Kennedy, D. O.; Scholey, A. B.; Wesnes, K. A. The dose dependent cognitive effects of acute administration of Ginkgo biloba to healthy young volunteers. Psychopharmacology $\mathbf{2 0 0 0}$, 151, 416-423.

(18) Polich, J.; Gloria, R. Cognitive effects of a Ginkgo biloba/ vinpocetine compound in normal adults: systematic assessment of perception, attention and memory. Hum. Psychopharmacol. Clin. Exp. 2001, 16, 409-416.

(19) Rigney, U.; Kimber, S.; Hindmarch, I. The effects of acute doses of standardized Ginkgo biloba extract on memory and psychomotor performances in volunteers. Phytother. Res. 1999, 13 408-415.

(20) Stough, C.; Clarke, J .; Lloyd, J .; Nathan, P. J . Neuropsychological changes after 30-day Ginkgo biloba administration in healthy patients. Int. J . Neuropsychopharmacol. 2001, 4, 131-134. 
(21) Braquet, P.; Spinnewyn, B.; Braquet, M.; Bourgain, R. H.; Taylor, J. E.; Etienne, A.; Drieu, K. BN 52021 and related compounds: a new series of highly specific PAF-acether antagonists isolated from Ginkgo biloba L. Blood Vessels 1985, 16, 559-572.

(22) Ishii, S.; Shimizu, T. Platelet-activating factor (PAF) receptor and genetically engineered PAF receptor mutant mice. Prog. Lipid Res. 2000, 39, 41-82.

(23) Prescott, S. M.; Zimmerman, G. A.; Stafforini, D. M.; Mcl ntyre, T. M. Platelet-activating factor and related lipid mediators. Annu. Rev. Biochem. 2000, 69, 419-445.

(24) Shukla, S. D. Platelet activating factor. Biomembranes 1996, 2B 463-479.

(25) Bito, $\mathrm{H}$ : Nakamura, M. Honda, $\mathrm{Z}$ : I zumi, T. I watsubo, T. Seyama, Y.; Ogura, A.; Kudo, Y.; Shimizu, T. Platelet-activating factor (PAF) receptor in rat brain: PAF mobilizes intracelluar $\mathrm{Ca}^{2+}$ in hippocampal neurones. Neuron 1992, 9, 285-294.

(26) Mori, M.; Aihara, M.; Kume, K.; Hamanoue, M.; Kohsaka, S.; Shimizu, T. Predominant expression of platelet-activating factor receptor in the rat brain microglia. J . Neurosci. 1996, 16, 35903600

(27) Kroegel, C.; Kortsik, C.; Kroegel, N.; Matthys, H. The pathophysiological role and therapeutic implications of platelet activating factor in diseases of aging. Drugs Aging 1992, 2, 345355.

(28) Perry, S. W.; Hamilton, J . A.; Tjoelker, L. W.; Dbaibo, G.; Dzenko, K. A.; Epstein, L. G.; Hannun, Y.; Whittaker, J . S.; Dewhurst, S.; Gel bard, H. A. Platelet-activating factor receptor activation. An initiator step in HIV-1 neuropathogenesis. J. Biol. Chem. 1998, 273, 17660-17664.

(29) Kato, K.; Clark, G. D.; Bazan, N. G.; Zorumski, C. F. Plateletactivating factor as a potential retrograde messenger in CA1 hippocampal long-term potentiation. Nature 1994, 367, 175179.

(30) Kornecki, E.; Wieraszko, A.; Chan, J . C.; Ehrlich, Y. H. Platelet activating factor (PAF) in memory formation: Role as a retrograde messenger in long-term potentiation. J . Lipid Mediators Cell Signalling 1996, 14, 115-126.

(31) Chen, C.; Magee, J. C.; Marcheselli, V.; Hardy, M.; Bazan, N. G. Attenuated LTP in hippocampal dentate gyrus neurons of mice deficient in the PAF receptor. J . Neurophysiol. 2001, 85, 384-390.

(32) Kobayashi, K. Ishii, S: Kume, K.: Takahashi, T. Shimizu, T. Manabe, T. Platelet-activating factor receptor is not required for long-term potentiation in the hippocampal CA1 region. Eur. . Neurosci. 1999, 11, 1313-1316.

(33) Smith, P. F.; Maclennan, K.; Darlington, C. L. The neuroprotective properties of the Ginkgo biloba leaf: a review of the possible relationship to platelet-activating factor (PAF). J. Ethnopharmacol. 1996, 50, 131-139.

(34) Smith, P. F.; Maclennan, K. The therapeutic potential of PAF receptor antagonists in CNS disorders. Curr. Opin. Anti-I nflammatory I mmunomodulatory I nvest. Drugs 1999, 1, 205-218.

(35) Corey, E. J .; Ghosh, A. K. Total synthesis of ginkgolide A. Tetrahedron Lett. 1988, 29, 3205-3206.

(36) Corey, E. J .; Kang, M. C.; Desai, M. C.; Ghosh, A. K.; Houpis, I. N. Total synthesis of $( \pm)$-ginkgolide B. J . Am. Chem. Soc. 1988, $110,649-651$

(37) Corey, E. J .; Su, W. G. Total synthesis of a $C_{15}$ ginkgolide, ( \pm )bilobalide. J. Am. Chem. Soc. 1987, 109, 7534-7536.

(38) Corey, E. J .; Gavai, A. V. Simple anal ogues of ginkgolide B which are highly active antagonists of platelet activating factor. Tetrahedron Lett. 1989, 30, 6959-6962.

(39) Corey, E. J .; Rao, K. S. Enantioselective total synthesis of ginkgolide derivatives lacking the tert-butyl group, an essential structural subunit for antagonism of platelet activating factor. Tetrahedron Lett. 1991, 32, 4623-4626.

(40) Park, P.-U.; Pyo, S.; Lee, S.-K.; Sung, J. H.: Kwak, W. J .; Park, H.-K.; Cho, Y.-B.; Ryu, G. H.; Kim, T. S. Ginkgolide derivatives. U.S. Patent 5,541,183, 1996.

(41) Hu, L.; Chen, Z.; Cheng, X.; Xie, Y. Chemistry of ginkgolides: structure-activity relationship as PAF antagonists. PureAppl. Chem. 1999, 71, 1153-1156.

(42) Hu, L.; Chen, Z.; Xie, Y.; Jiang, H.; Zhen, H. Alkyl and alkoxycarbonyl derivatives of ginkgolide $\mathrm{B}$ : synthesis and biological evaluation of PAF inhibitory activity. Bioorg. Med. Chem. 2000, 8, 1515-1521.
(43) Hu, L.; Chen, Z.; Xie, Y.; J iang, Y.; Zhen, H. New products from alkali fusion of ginkgolides A and B. J. Asian Nat. Prod. Res. 2000, 2, 103-110.

(44) Hu, L.; Chen, Z.; Xie, Y. Synthesis and biological activity of amide derivatives of ginkgolide A. J. Asian Nat. Prod. Res. 2001, 3, 219-227.

(45) Dorman, G.; Prestwich, G. D. Using photolabile ligands in drug discovery and development. Trends Biotechnol. 2000, 18, 6477.

(46) Flemming, S. A. Chemical reagents in photoaffinity labeling. Tetrahedron 1995, 51, 12479-12520.

(47) Kotzyba-Hilbert, F.; Kapfer, I.; Goeldner, M. Recent trends in photoaffinity labeling. Angew. Chem., Int. Ed. Engl. 1995, 34 $1296-1312$.

(48) Nassal, M. 4-(1-Azi-2,2,2-trifluoroethyl)benzoic acid, a highly photolabile carbene generating label readily fixable to biochemical agents. Liebigs Ann. Chem. 1983, 1510-1523.

(49) Nassal, M. 4'-(1-Azi-2,2,2-trifluoroethyl)phenylalanine, a photolabile carbene-generating analogue of phenylalanine. J. Am Chem. Soc. 1984, 106, 7540-7545.

(50) Keana, J. F. W.; Cai, S. X. New reagents for photoaffinity labeling: synthesis and photolysis of functionalized perfluorophenyl azides. J . Org. Chem. 1990, 55, 3640-3647.

(51) Lei, H. Marks, V. Pasquale, T. Atkinson, J. K. Synthesis of photoaffinity label analogues of $\alpha$-tocopherol. Bioorg. Med. Chem Lett. 1998, 8, 3453-3458.

(52) Lei, H.; Atkinson, J . Synthesis of phytyl- and chroman-derivatized photoaffinity labels based on $\alpha$-tocopherol. J . Org. Chem. 2000, 65, 2560-2567.

(53) Shindou, H.; I shii, S.; U ozumi, N.; Shimizu, T. Roles of cytosolic phopholipase A2 and platelet-activating factor receptor in the Ca-induced biosynthesis of PAF. Biochem. Biophys. Res. Commun. 2000, 271, 812-817.

(54) Li, H.; Liu, Y.; Fang, K.; Nakanishi, K. A simple photoaffinity labeling protocol. Chem. Commun. 1999, 365-366.

(55) Maclennan, K. M.; Smith, P. F.; Darlington, C. L. The effects of ginkgolide B (BN52021) on guinea pig vestibular nucleus neurons in vitro: importance of controlling for effects of dimethyl sulfoxide (DMSO) vehicles. Neurosci. Res. 1996, 26, 395-399.

(56) Fukunaga, K.; Ishii, S.; Asano, K.; Yokomizo, T.; Shiomi, T.; Shimizu, T.; Yamaguchi, K. Single nucleotide polymorphism of human platelet-activating factor receptor impairs G-protein activation. J . Biol. Chem. 2001, 276, 43025-43030.

(57) Aoki, Y.; Nakamura, M.; Kodama, H.; Matsumoto, T.; Shimizu, T.; Noma, M. A radioreceptor binding assay for platelet-activating factor (PAF) using membranes from $\mathrm{CHO}$ cells expressing human PAF receptor. J . I mmunol. Methods 1995, 186, 225231.

(58) Corey, E. J .: Rao, K. S.: Ghosh, A. K. Intramolecular and intermolecular hydroxyl reactivity differences in ginkgolides A $B$ and $C$ and their chemical applications. Tetrahedron Lett. 1992, 33, 6955-6958

(59) Weinges, K.; Schick, H. Chemie der Ginkgolid IV. Herstellung von Ginkgolid B aus Ginkgolid C. Liebigs Ann. Chem. 1991, 8183.

(60) Chen, J : Hu, L.; J iang, H.; Gu, I : Zhu, W.; Chen, Z: Chen., K. $\mathrm{J}$ i, R. A 3D-QSAR study on ginkgolides and their anal ogues with comparative molecular field analysis. Bioorg. Med. Chem. Lett. 1998, 8, 1291-1296.

(61) van Beek, T. A.; Lelyved, G. P. Preparative isolation and separation procedure for ginkgolides A, B, C, and J and bilobalide. J . Nat. Prod. 1997, 60, 735-738.

(62) Ishii, S.; Nagase, T.; Tashiro, F.: I kuta, K.; Sato, S.; Waga, I. Kume, K.; Miyazaki, J .; Shimizu, T. Bronchial hyperreactivity, increased endotoxin lethality and melanocytic tumorigenesis in transgenic mice overexpressing platel et-activating factor receptor. EMBO I. 1997, 16, 133-142.

(63) Bradford, M. M. A rapid and sensitive method for the quantitation of microgram quantities of protein utilizing the principle of protein-dye binding. Anal. Biochem. 1976, 72, 248-254.

(64) Cheng, Y.; Prusoff, W. H. Relationship between the inhibition constant $\left(\mathrm{K}_{\mathrm{i}}\right)$ and the concentration of inhibitor which causes $50 \%$ inhibition $\left(I_{50}\right)$ of an enzymatic reaction. Biochem. Pharmacol. 1973, 22, 3099-3103.

J M 020147W 